\title{
Effect of summer fire on cursorial spider (Aranei) and beetle (Coleoptera) assemblages in meadow steppes of Central European Russia
}

\author{
Nina Polchaninova ${ }^{1, *}$, Mikhail Tsurikov ${ }^{2}$ \& Andrey Atemasov ${ }^{3}$
}

Key words: arthropod assemblage, Galich'ya Gora, meadow steppe, summer fire.

\author{
Ključne besede: združba \\ členonožcev, Galičija Gora, \\ travniška stepa, poletni požar.
}

Received: 16.12 .2015

Accepted: 9. 7.2016

Co-ordinating Editor: Stephen Venn

\begin{abstract}
Fire is an important structuring force for grassland ecosystems. Despite increased incidents of fire in European steppes, their impact on arthropod communities is still poorly studied. We assessed short-term changes in cursorial beetle and spider assemblages after a summer fire in the meadow steppe in Central European Russia. The responses of spider and beetle assemblages to the fire event were different. In the first post-fire year, the same beetle species dominated burnt and unburnt plots, the alpha-diversity of beetle assemblages was similar, and there were no pronounced changes in the proportions of trophic groups. Beetle species richness and activity density increased in the second post-fire year, while that of the spiders decreased. The spider alpha-diversity was lowest in the first postfire year, and the main dominants were pioneer species. In the second year, the differences in spider species composition and activity density diminished. The main conclusion of our study is that the large-scale intensive summer fire caused no profound changes in cursorial beetle and spider assemblages of this steppe plot. Mitigation of the fire effect is explained by the small plot area, its location at the edge of the fire site and the presence of adjacent undisturbed habitats with herbaceous vegetation.
Izvleček
V strukturiranju travniških ekosistemov je ogenj pomemben dejavnik. Kljub povečanem številu požarov v evropskih stepah, je njihov vpliv na združbe členonožcev slabo raziskan. Preučili smo kratkotrajne spremembe na združbe talnih pajkov in hroščev po poletnih požarih v travniški stepi srednje evropske so na pogorelih in nepogorelih ploskvah prevadovale iste vrste hroščev, alfa diverziteta združb hroščev je bila podobna in ni bilo opaznih razlik v trofičnih o požaru, pri pajkih pa sta se zmanjšala. Alfa diverziteta pajkov je bila najnižja prvo leto po požaru in prevladovale so pionirske vrste. Drugo leto so se razlike v vrstni sestavi pajkov in številu osebkov zmanjšale. Glavni zaključek naše raziskave je, da intenzivni velikopovršinski poletni požari v stepi ne povzročijo močnih sprememb v združbah hroščev in pajkov. Zmanjšanje učinka požara razložimo z majhnimi površinami ploskev, njihovim položajem na robu požarišča in prisotnostjo nedotaknjenih površin z zeliščno vegetacijo $\mathrm{v}$ bližini. Rusije. Odzivi pajkov in hroščev na požar so bili različni. V prvem letu po požaru skupinah. Vrstna pestrost hroščev in število osebkov sta se povečala v drugem letu
\end{abstract}

\footnotetext{
1 Department of Zoology and Animal Ecology, V. N. Karazin Kharkiv National University, 4, Svobody Sq., Kharkiv, 61022, Ukraine. E-mail: polchaninova_n@ukr.net

2 Voronezh State University, “Galich'ya Gora” Reserve, Donskoye Vil., 223, Naberezhnaya St., Lipetsk Region, 399240, Russia. E-mail: mntsurikov@rambler.ru

3 Research Institute of Biology, V. N. Karazin Kharkiv National University. E-mail: atemasov@gmail.com

* Corresponding author
} 


\section{Introduction}

Fire is a ubiquitous natural disturbance, which plays a key role in the maintenance of many landscapes. Humans have always coexisted with natural fires and used prescribed burning (Bowman et al. 2009, Archibald et al. 2012, Deák et al. 2014). Controlled fires are recommended as a conservation tool for the maintenance of biodiversity (Richards et al. 1999, Orgeas \& Andersen 2001, Parr \& Chown 2006), while anthropogenic uncontrolled fires cause harm to human health, result in economical losses and affect biodiversity (Bowman et al. 2009, Chibilev 2014, Deák et al. 2014).

Every fire leaves an imprint on the landscape, and the numerous variables that influence fire behavior can generate unpredictable consequences (New 2014). Besides the five key characteristics of the fire regimes of size, frequency, intensity, season and extent (Bond \& Keele 2005, Archibald et al. 2012), it is also necessary to consider the type of ecosystem, local microclimatic conditions at the fire site, meteorological conditions in the pre and post-fire period and the surrounding habitat mosaic, for instance (Kitzeberg et al. 1999, Chuvieco et al. 2008, Sackmann \& Farji-Brener 2006). Therefore, despite numerous studies that describe various fire cases and/or analyze general regularities within continents or ecosystems, the impacts of fire on different biota components is still not fully understood (Chuvieco et al. 2008, Griffiths \& Brook 2014, Chibilev 2014). Most of the conclusions and recommendations for fire management are based on vegetation studies within a framework intended primarily to maintain plant diversity. Animal populations are not taken into consideration because of information gaps (Parr \& Chown 2003, Griffiths \& Brook 2014, New 2014).

Fire can increase, decrease, or have no effect on arthropod diversity (Swengel 2001, Sackmann \& Farji-Brener 2006, Cook \& Holt 2006). These effects depend on characteristics of both the fire and the species' capacity to tolerate disturbance and adapt to post-fire conditions (New 2014). Within the same taxa, there can be species with different ecological requirements and, consequently, different responses to the fire event. Invertebrate species that are associated during some stages of their life cycle with litter or dead stems are particularly vulnerable. The recovery of their numbers and species composition in grassland ecosystems may extend over several years (Swenge 1996, Panzer 2002, Vogel et al. 2010, Polchaninova 2015). Mobile epigeic arthropods colonize fire sites faster (Panzer 2002, Prishutova \& Arzanov 2004, Savchenko 2009) but exhibit changes in trophic structure (Guseva \& Bogach 1988), ecological group proportions (Savchenko 2009,
Prokopenko \& Savchenko 2013) or deep changes in assemblage composition (Nemkov \& Sapiga 2010, Robinson et al. 2013, Kwok \& Eldridge 2015, Polchnainova 2015). The latter occurs in the case of repeated catastrophic fires of large areas with no refuges for small animals.

As many taxa as possible should be included in the analysis of the effects of fire on arthropod assemblages in order to better understand the complex ecological interactions involved and minimize the risk of making general statements based on studies of a limited number of taxa (Prodon et al. 1987). Spiders and beetles are the most abundant orders of ground-dwelling arthropods in dry grassland communities (Sumu et al. 2010). Only in some cases are they less abundant than ants (personal observations). Both orders include species with a variety of habitat preferences, and differences in trophic ecology. Thus, they can serve as a good model for studying the impact of disturbance on steppe ecosystems. The aim of our research is to investigate short-term changes in cursorial spider and beetle assemblages after a summer fire at a small isolated plot of meadow steppe.

\section{Methods}

The research was carried out in the "Galich'ya Gora" Nature Reserve (Lipetsk Region, Russia) located in the east of the Central Russian Upland (Figure 1). The area in question lies in the centre of the Middle Russian ForestSteppe, at the border of its northern and southern sub-

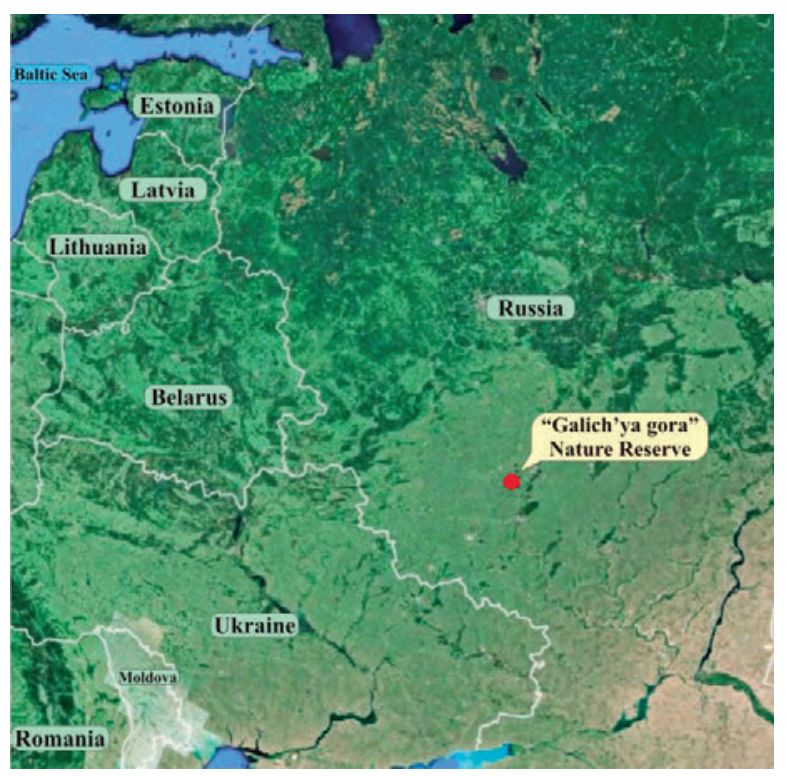

Figure 1: Location of the study site in the East European Plain. Slika 1: Lokacija preučevanega območja v Ruskem nižavju. 


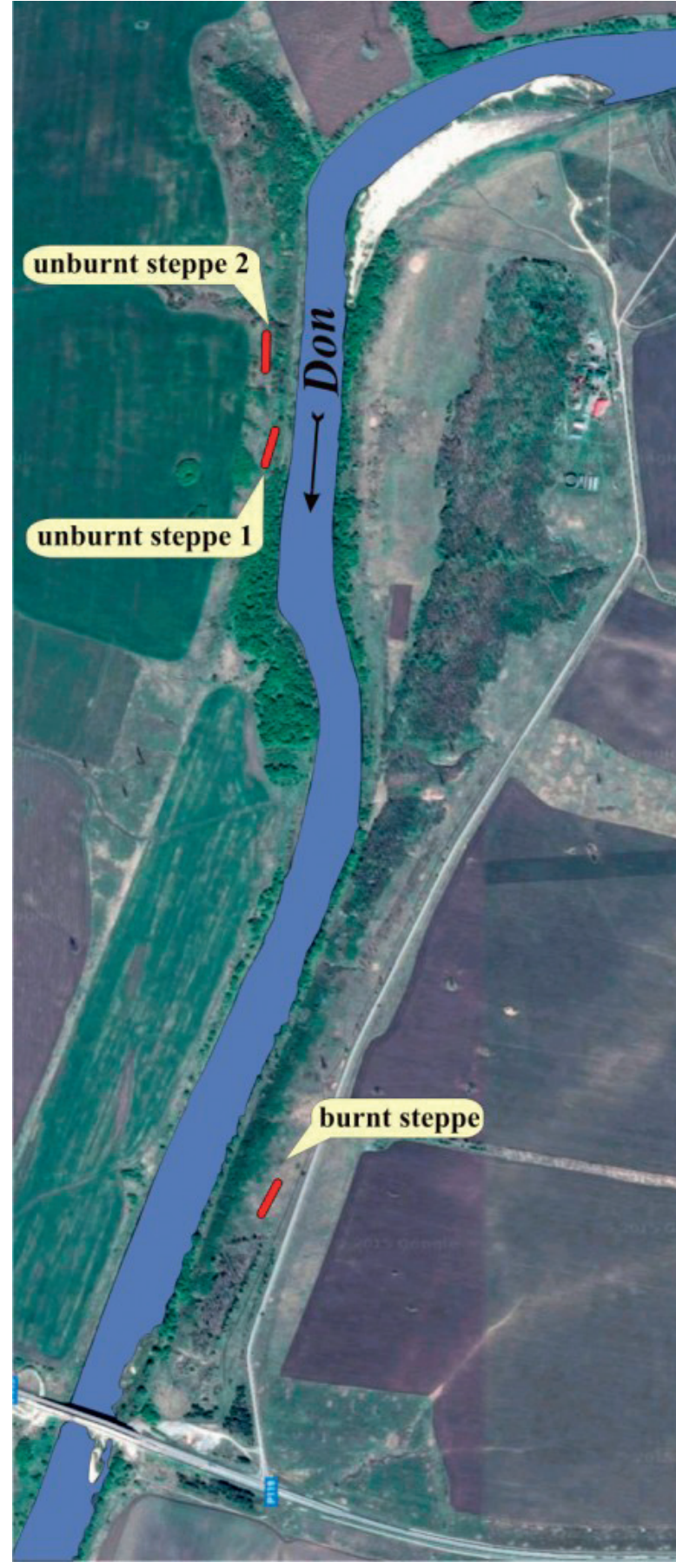

Figure 2: Location of the sample plots in the "Galich'ya Gora" Reserve. Burnt steppe - feather-grass - forb steppe at the Morozova Gora site; unburnt steppe 1 - feather-grass - forb steppe at the Galich'ya gora site, unburnt steppe 2 - shrub steppe at the same site; the red lines - transects of pitfall traps.

Slika 2: Lokacije vzorčnih ploskev v rezervatu "Galičija Gora". Požgana stepa - stepa z bodalico in zelišči na lokaciji Morozova Gora; nepogorela stepa 1 - stepa z bodalico in zelišči na lokaciji Galičija Gora, nepogorela stepa 2 - stepa z grmišči na isti lokaciji; rdeča črta transekt $s$ talnimi pastmi. zones (Aleksandrova 1992). The sample plots were located at the Morozova Gora $\left(52^{\circ} 35^{\prime} 51.83^{\prime \prime N}\right.$, 38 $\left.55^{\circ} 27.62 " \mathrm{E}\right)$ and Galich'ya Gora $\left(52^{\circ} 36^{\prime} 4.01^{\prime \prime N}, 38^{\circ} 55^{\prime} 4.22^{\prime \prime E}\right)$ sites, which are parts of the Reserve. The total area of the first site is 100 ha, of which meadow steppe occupies 10 ha, and the area of the second site is 19 ha, including eight hectares of steppe (Figure 2). At both sites, steppe habitats adjoin shrub thickets, oak stands and/or a small pine plantation. The average daytime temperature of the east-facing limestone riverbank at the Galich'ya Gora site and its vicinity is higher than that on the west-facing riverbank at the Morozova Gora (Skufyin 1978).

The feather-grass - forb steppe at the Morozova Gora is dominated by Bromopsis inermis (Leyss.) Holub, Poa angustifolia L., Galium verum L., Fragaria viridis Duch., Stipa pennata L., Hieracium virosum Pall., Carex humilis Leyss., Calamagrostis epigeios (L.) Roth, and Elytrigia intermedia (Host) Nevski. At the Galich'ya Gora, S. pennata L., S. capillata L., P. pratensis L., Potentilla arenaria Borkh., C. praecox Schreber are dominants of the feathergrass - forb steppe, while Melica transsilvanica Schur, P. angustifolia L., Calamagrostis epigeios (L.) Roth, Spiraea crenata L., Cerasus fruticosa Pall. and Chamaecytisus ruthenicus (Fischer ex Wołoszczak) Ktásková prevail in the shrub steppe (Nedosekina et al. 2009).

On 29 July 2010, an uncontrolled anthropogenic fire, with its origin in adjacent agricultural fields, burnt nearly the whole Morozova Gora site (Figure 3). Galich'ya

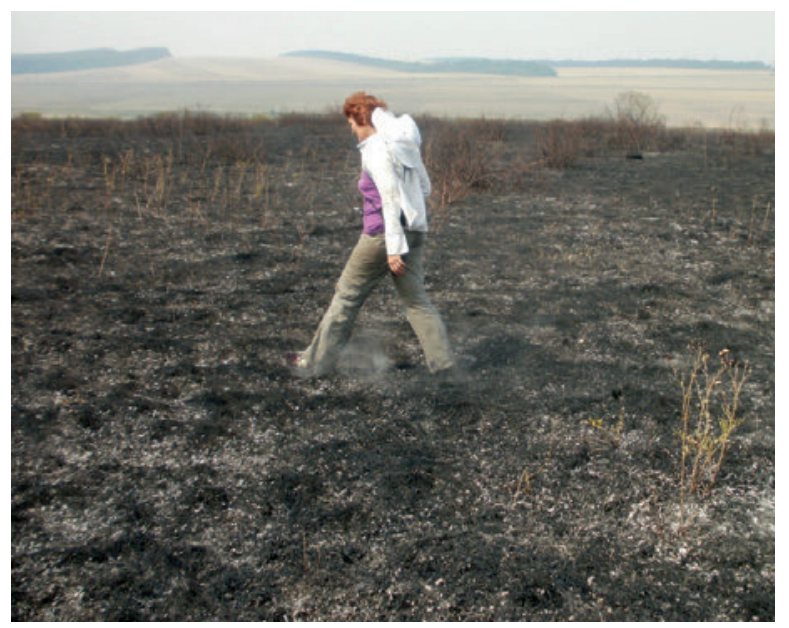

Figure 3: Morozova Gora, $30^{\text {th }}$ July 2010, the day after the fire. Slika 3: Morozova Gora, 30. 7. 2010, dan po požaru.

Gora, which is located on the opposite bank of the river, remained unaffected by the fire. We studied the recovery of the cursorial spider and beetle assemblages in the first (2011) and second (2012) post-fire years. A transect of 10 traps, inserted at 10 meter intervals, was established in the burnt feather-grass - forb steppe at the Morozova Gora 


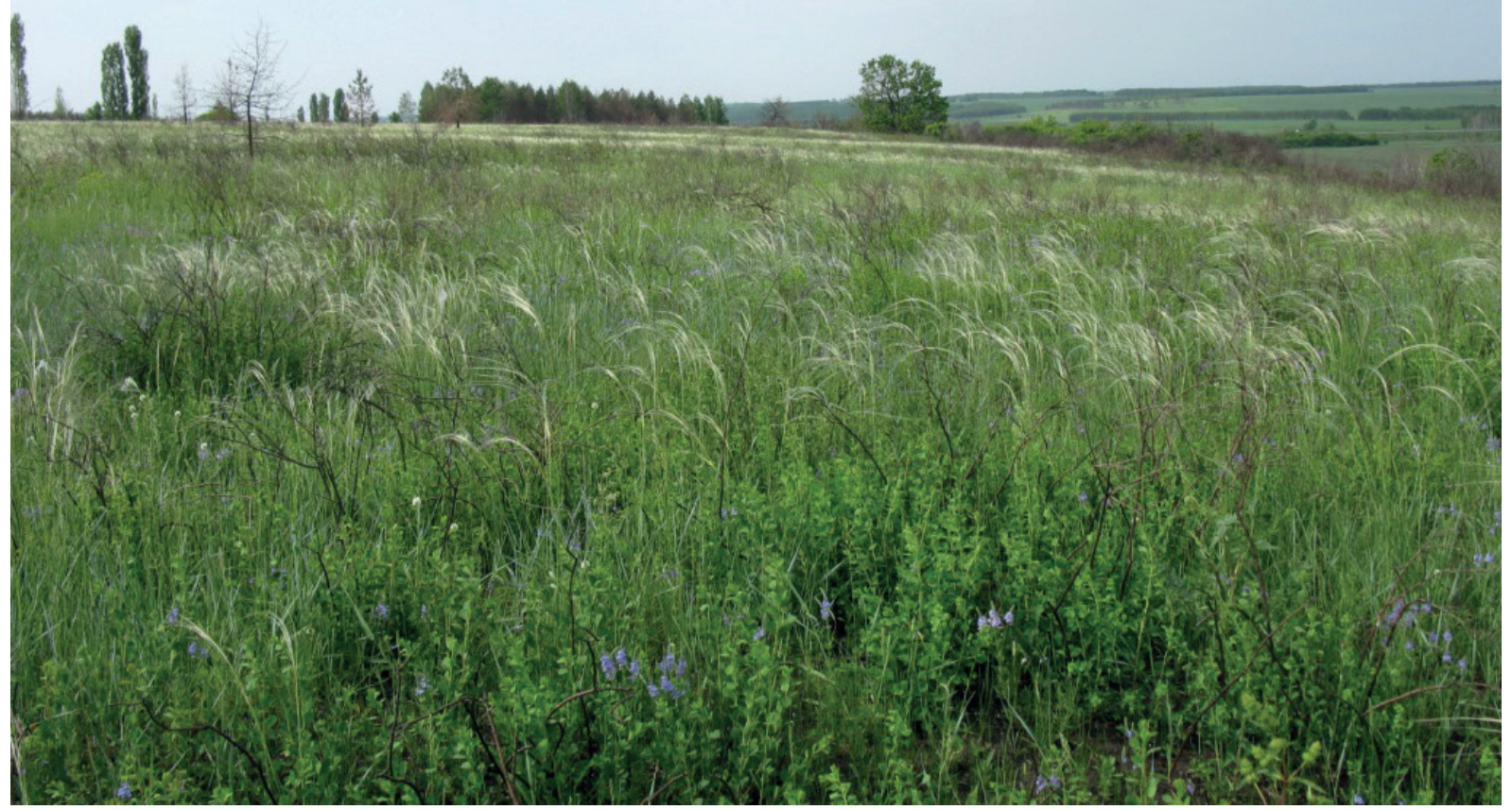

Figure 4: Morozova Gora, 24 $4^{\text {th }}$ May 2011, burnt plot, feather grass - forb steppe.

Slika 4: Morozova Gora, 24. 5. 2011, požgana ploskev - stepa z bodalico in zelišči.

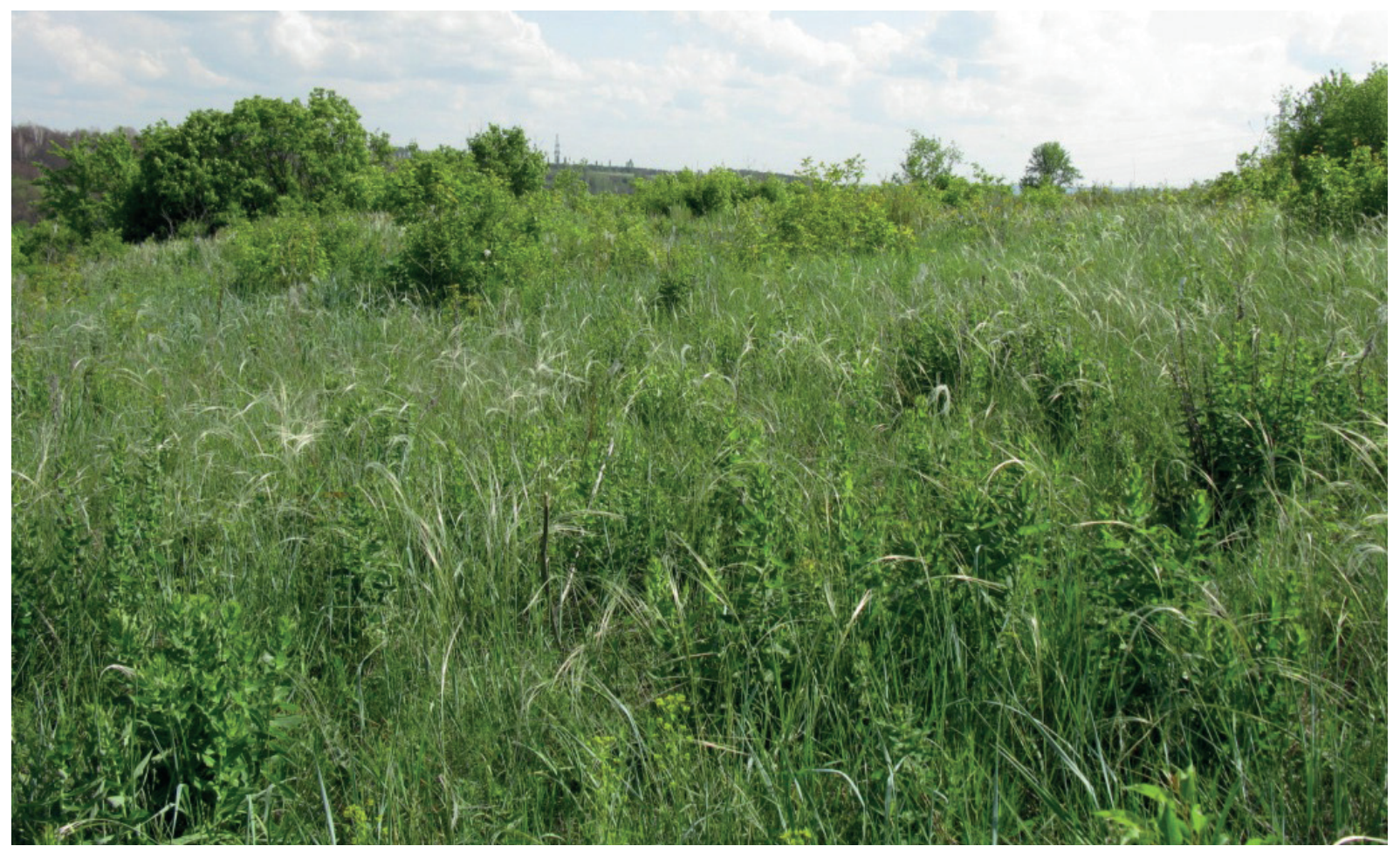

Figure 5: Galich'ya Gora, 25 $5^{\text {th }}$ May 2011, unburnt control-1, feather grass - forb steppe.

Slika 5: Galičija Gora, 25. 5. 2011, nepogorela kontrola-1, stepa z bodalico in zelišči. 
site (Figure 2, 4) and, as a control, in the feather-grass-forb steppe (Figure 5) and shrub steppe (Figure 6) at the Galich'ya Gora site (subsequently referred to as burnt plot, control-1 and control-2 plots). The distance between the burnt and unburnt plots was about 1.5-1.9 km (Figure 2).

The pitfall traps comprised plastic cups of $6.5 \mathrm{~cm}$ diameter containing $4 \%$ formalin as a fixative. The traps were emptied approximately once a month during the periods 24.05-29.07.2011 and 26.04-4.08.2012. During the two years, a total of 1998 beetles and 424 spiders were collected at the burnt plot, 1430 beetles and 355 spiders at the control-1, and 2191 beetles and 498 spiders at the control-2.

When comparing the data of 2011 and 2012, we excluded the material collected during 26.04-28.05.2012, as in the previous year no data was obtained during that period. We did use these samples for the assemblage comparison in 2012. Juvenile specimens of the ground-dwelling spiders cannot be identified to the species level; therefore we excluded them from the comparison of species diversity but included them in the assessment of spider activity density.

In terms of food preferences of the beetle imagos, we distinguished eleven guilds: zoophagous, zoo-phytophagous, necro-zoophagous, phytophagous, sapro-phytophagous, phyto-saprophagous, saprophagous, mycetophagous, necrophagous, coprophagous, lichenophagous (after Vassiliev 1987, Dedyu 1990), and a group of unknown feeding-type.
Relative abundance was estimated using the Southwood rating scale: superdominants $>20 \%$, dominants $10.1-20 \%$, subdominants $5.1-10 \%$ and recedents $<5 \%$ (Southwood 1978). Superdominants and dominants comprised a dominant complex. The alpha-diversity of the spider and beetle assemblages was assessed by the method of multifractal analysis, which combines information on various aspects of ecological diversity. An advantage of this method is its sensitivity, which facilitates the identification of structural features of communities with similar information indices, in particular, the diversity indices (Gelashvili et al. 2013). Graphic interpretation of this method represents the proportion of species in the arthropod assemblages at each study plot along the $\mathrm{x}$-axis and the species diversity of each assemblage along the $y$-axis. The left branch of the spectrum characterizes presence, and/or ratio, of dominant species in the community, while the right branch characterizes rare species. The spectrum-width reflects the degree of contrast between rare and dominant species (Gelashvili et al. 2012).

We applied Detrended Correspondence Analysis (DCA) (Hill \& Gauch 1980) to determine the differences between spider and beetle assemblages at the burnt and unburnt plots in the two post-fire years. The ordination was performed in the program PAST 3.4 (Hammer et al. 2001).

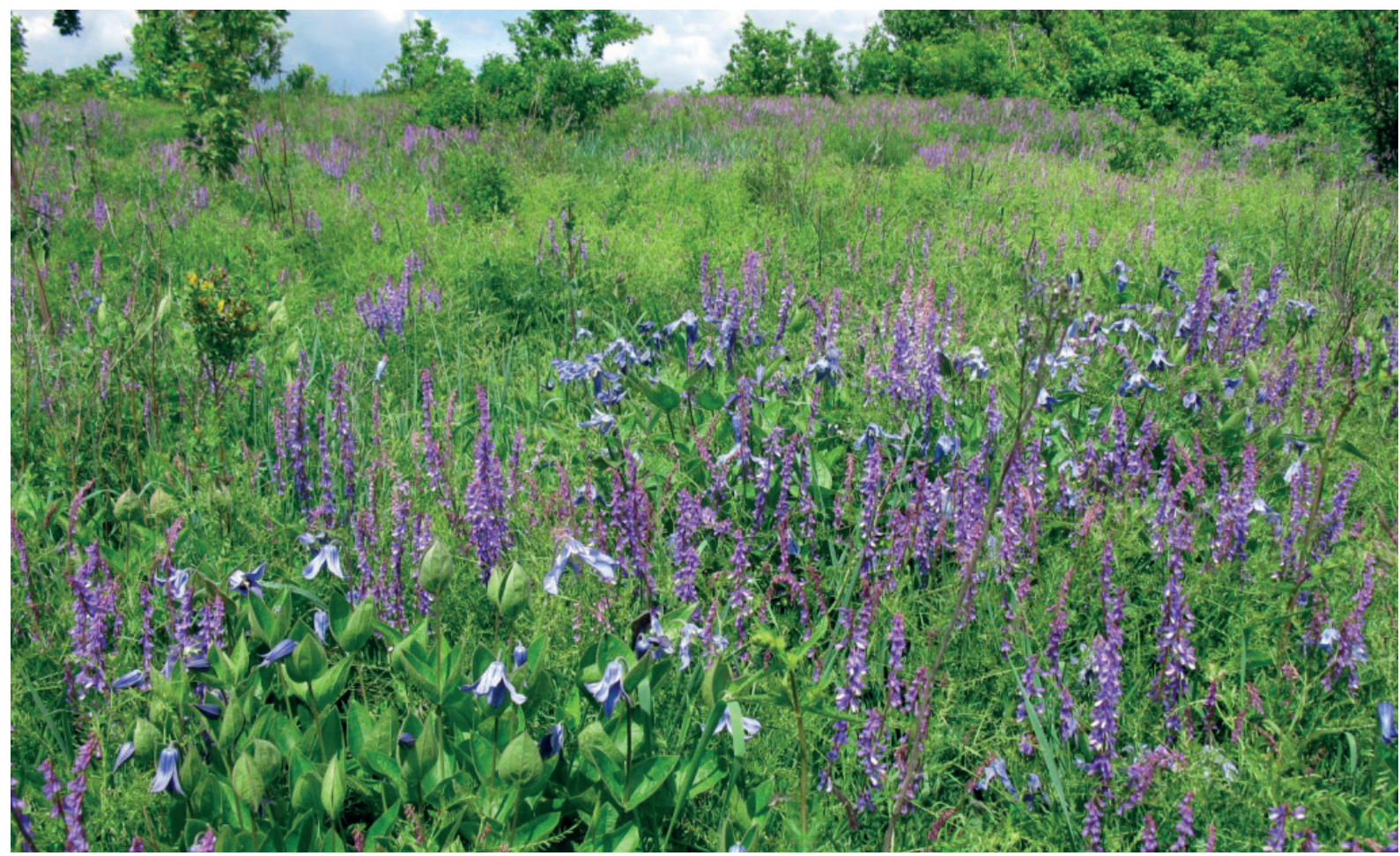

Figure 6: Galich'ya Gora, 25 $5^{\text {th }}$ May 2011, unburnt control-2, shrub steppe. Slika 6: Galičija Gora, 25. 5. 2011, nepogorela kontrola-2, stepa z grmišči. 


\section{Results}

\section{Beetle species richness and abundance}

Fifty-six beetle species from 16 families were recorded in the first post-fire year from the Morozova Gora site (Appendix, Table 1). The families Carabidae (21 species) and Curculionidae (eight species) were the most species-rich. The former family also dominated in number of individuals (252 specimens), while Tenebrionidae was the second most abundant (137 specimens). Three dominant species, Harpalus rufipes (Carabidae), Dermestes laniarius (Dermestidae) and Crypticus quisquilius (Tenebrionidae), comprised altogether $49 \%$ of the collected beetles (Figure 7).

At the Galich'ya Gora site, 51 beetle species from 14 families were recorded from the unburnt control-1, and 103 species from the unburnt control-2 (Appendix, Table 1). At the former plot, the species richness of the Carabidae and Curculionidae was nearly equal (15 and 13 species, respectively), the number of individuals of the Tenebrionidae was slightly larger than that of the Carabidae (135 vs. 113 specimens). The dominant complex included the same three species as at the burnt plot (Figure 7 ), their relative abundance reaching $57 \%$ of the total number of individuals (1005). At the second plot, the proportion of Carabidae and Curculionidae species was similar to that of the burnt plot (22 vs. 9); the families Silphidae (186) and Carabidae (172) prevailed in individual numbers. In the dominant complex, Silpha obscura replaced Crypticus quisquilius (Figure 7), and the relative abundance of dominant species increased to $67 \%$.

In May-June 2012, the beetle assemblage of the burnt plot was represented by 62 species from 17 families. The Carabidae and Curculionidae abundance increased to 21-22 species each. The Tenebrionidae reached extremely high numbers (527 specimens) because of the predominance of Crypticus quisquilius (57.9\% of total individuals). The Carabidae numbered only 123 individuals.

During the same period, 54 beetle species from 16 families were recorded from the control- 1 and 103 species from 25 families from the control-2 plots at Galich'ya Gora. At the first plot, the family Carabidae included 17 species and the Curculionidae 10 species; at the second plot, these families numbered 22 and 21 species, respectively. Two tenebrionids, Oodescelis melas (14\%) and Crypticus quisquilius (27.8\% of total individuals), comprised the dominant complex (Figure 7), and in general, the tenebrionids were more abundant (161 specimens) than the carabids (64 specimens). The second control plot, as in the previous year, was dominated by Silpha obscura $(26 \%)$ and Dermestes laniarius (12.8\%), but the third dominant, Urometo-

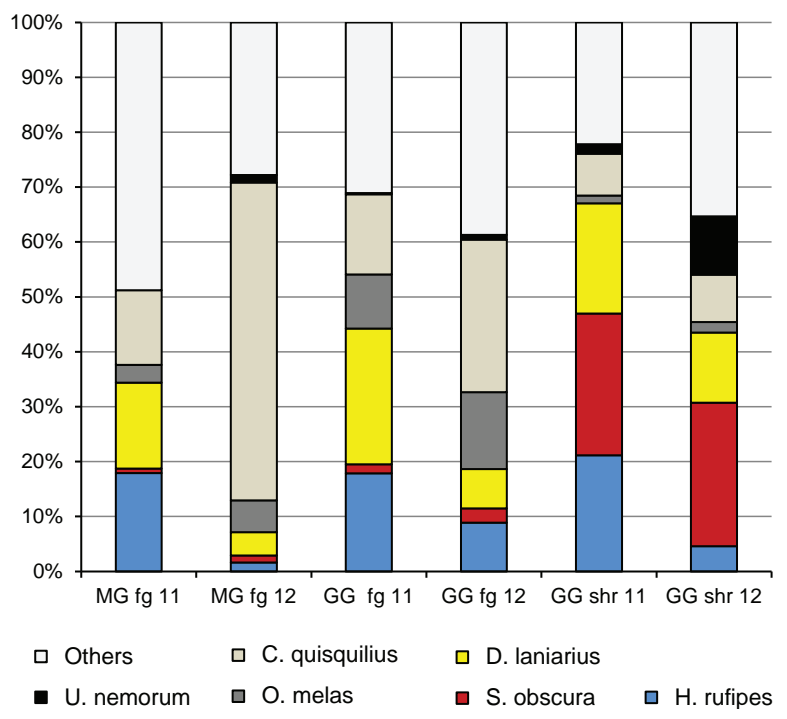

Figure 7: Relative abundance of dominant beetle species at the burnt and unburnt plots in 2011, 2012. MG - Morozova Gora (burnt), GG - Galich'ya Gora (unburnt), fg - feather-grass - forb steppe, shr shrub steppe.

Slika 7: Relativna abundanca prevladujočih vrst hroščev na pogorelih in nepogorelih ploskvah v letih 2011 in 2012. MG - Morozova Gora (pogorelo), GG - Galičija Gora (nepogorelo), fg - stepa z bodalico in zelišči, shr - stepa z grmišči.

pus nemorum (10.6\%), was new to the complex. Two families, Silphidae and Curculionidae, were the most abundant in individual numbers (231 and 153, respectively).

Early spring pitfall-trapping in 2012 contributed 28 species to the list of beetles at the burnt plot, 44 species at control-1, and 32 species at control-2. Opatrum sabulosum (22-30.7\% of total individuals), Dermestes laniarius (22.5-38\%) and Oodescelis melas (12.1-19.7\%) dominated at both burnt and control-1 plots. At control-2, there were only two dominants, D. laniarius (38.3\%) and $S$. obscura (17.1\%).

April-May 2012 was a period of peak beetle activity in terms of both species (51-77 species, depending on the plot) and individuals (180-219 individuals/100 trapdays) (Figure 8). Apart from this period, the beetle activity density at the burnt plot was higher than that at control-1. The average activity density in May-August 2011, 2012 was as follows: $96.2,65.4$, and 99.4 individuals/ 100 trap-days at the burnt, control- 1 and control-2 plots respectively in 2011, and 117.1, 51.2, and 124.4 individu$\mathrm{als} / 100$ trap-days in 2012 . The curve of species richness in the graph was similar at the three studied plots until May 2012, after which it dropped at both the burnt and control-1 plots, and gradually decreased at the control-2. At the burnt plots, there was only one marked peak of seasonal species richness, while at the burnt plot there were three peaks. 

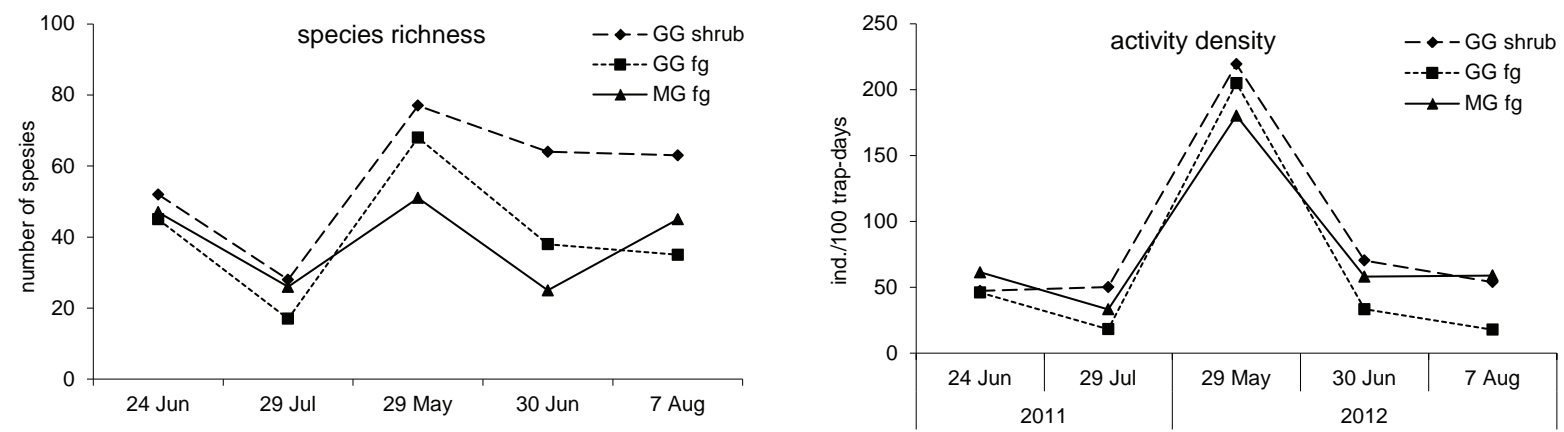

Figure 8: Seasonal dynamics of beetle assemblages at the burnt and unburnt plots. For abbreviations, see Figure 7.

Slika 8: Sezonska dinamika združb hroščev na pogorelih in nepogorelih ploskvah. Za okrajšave glej sliko 7.
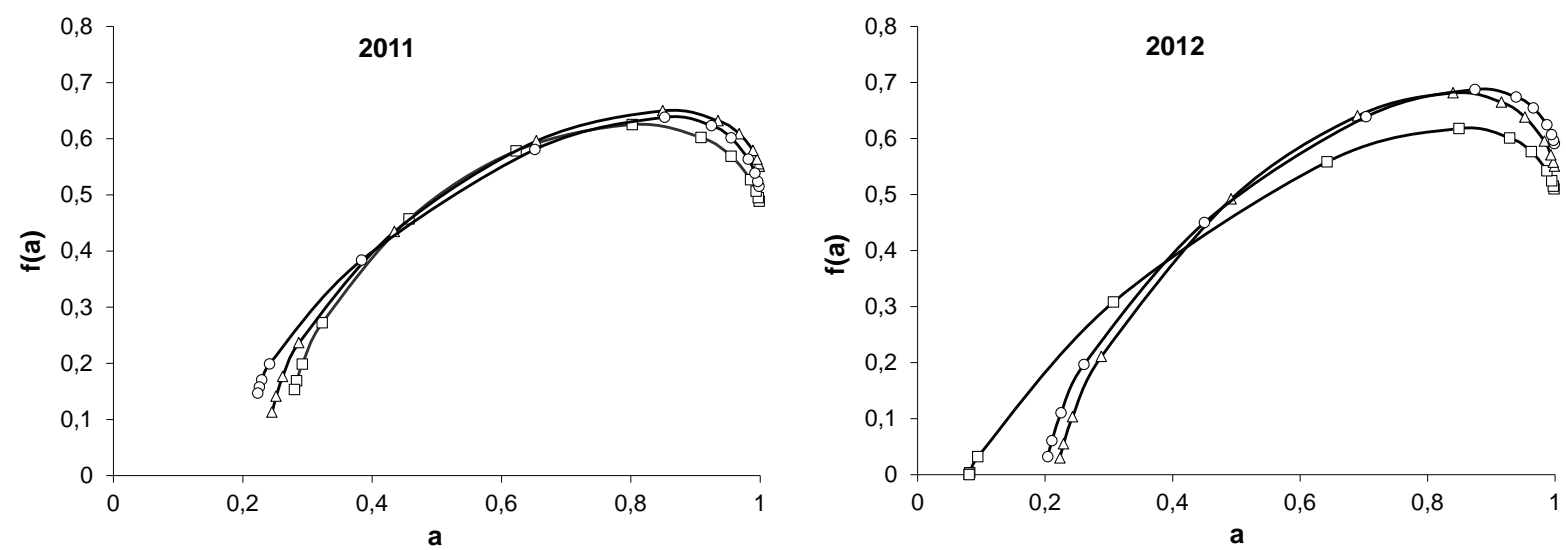

Figure 9: Multifractal spectrum of the beetle alpha-diversity at the burnt and unburnt plots. a - singularity index; $\mathrm{f}(\mathrm{a})$ multifractal spectrum function. - $\square$ - - MGfg; - $\Delta$ - - GGfg, - - - GGshr. For abbreviations, see Figure 7.

Slika 9: Multifraktalni spekter alfa diverzitete na pogorelih in nepogorelih ploskvah. a - singularity index; f(a) funkcija multifraktalnega spektra. - -- - MGfg; - $\Delta$ - - GGfg, - - - GGshr. Za okrajšave glej sliko 7.
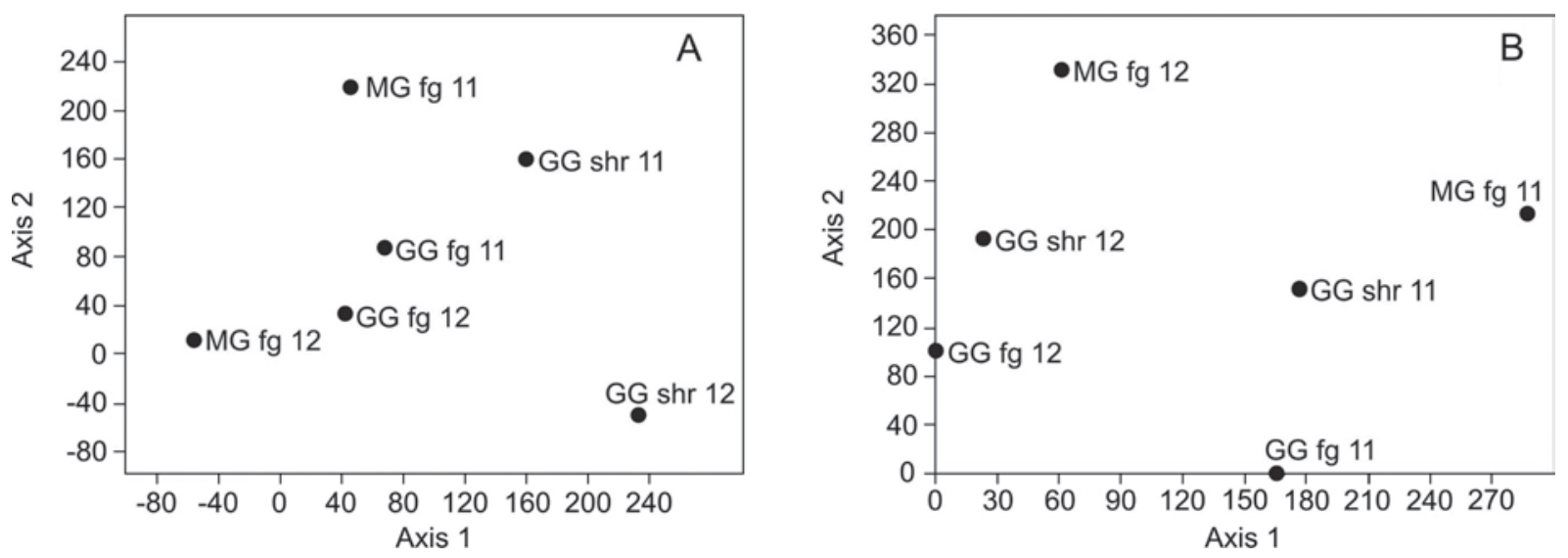

Figure 10: DCA ordination of beetle (A) and spider (B) assemblages at the burnt and unburnt plots. For abbreviations, see Figure 7.

Slika 10: DCA ordinacija združb hroščev (A) in pajkov (B) na pogorelih in nepogorelih ploskvah. Za okrajšave glej sliko 7.

The multifractal analysis shows that in 2011 the alphadiversity of beetle assemblages was similar at the three studied plots (Figure 9). In 2012, the diversity slightly increased at the unburnt plots and decreased at the burnt one. The DCA revealed little difference between the beetle assemblages for 2011 and 2012 at control-1 (Figure 10). Annual differences at the burnt plot and control-2 were much higher; the beetle assemblage for 2012 of the control-2 stands apart from the other assemblages along both axes. 


\section{Trophic guilds of beetles}

According to their feeding preferences, the collected beetles belonged to 11 guilds, of which the phytophagous and zoophagous guilds were the most species-rich (Figure 11). The number of phytophagous species did not change during the study years at the burnt plot and control-1, but more than doubled in 2012 at control-2, due to an increase in Curculionidae and Chrysomelidae species.

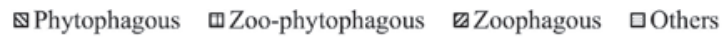

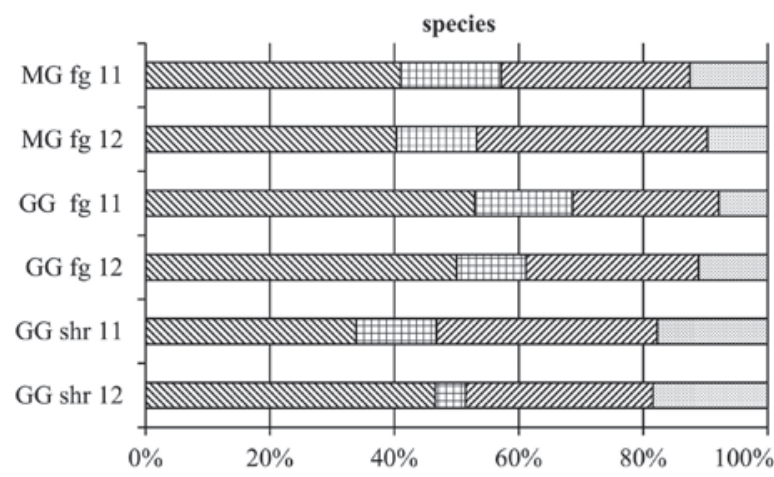

individuals

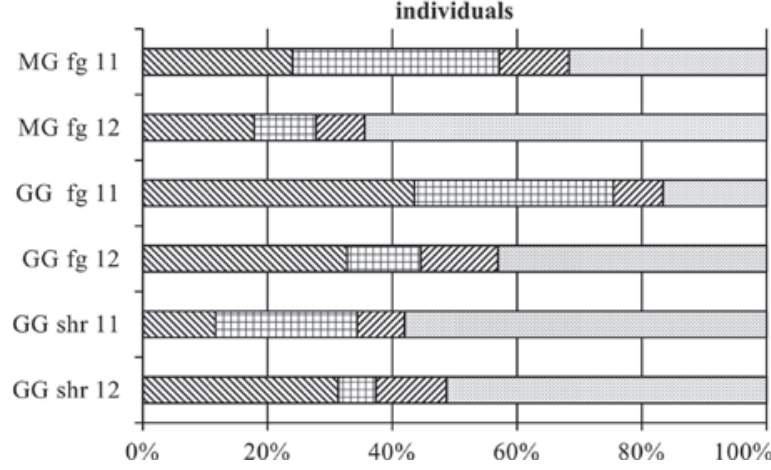

Figure 11: Relative abundance of the trophic groups of beetles at the burnt and unburnt plots. For abbreviations, see Figure 7.

Slike 11: Relativna abundanca trofičnih skupin hroščev na pogorelih in nepogorelih ploskvah. Za okrajšave glej sliko 7 .

In terms of proportions of individual numbers, the zoophytophagous guild decreased from $33 \%$ to $10 \%$ at the burnt plot in 2012 because of a decrease in numbers of Harpalus anxius, $H$. rubripes and $H$. rufipes. The increase in numbers of Crypticus quisquilius (Tenebrionidae), a sapro-phytophagous beetle, resulted in a higher representation of the "other species" group in 2012 (Figure 11). Dermestes laniarius, a species with unknown trophic preference, was also abundant in this group. The same annual changes in the guild proportions were observed at the unburnt control-1. In both years, the dominating Silpha obscura generated a high abundance of the necrophagous group at control-2. The proportion of phytophagous beetles increased from $20 \%$ in 2011 to $40 \%$ in 2012, due to the increase in the numbers of Sermylassa halensis, Urometopus nemorum and Stomodes gyrosicollis, while the zoophytophagous group decreased from $23 \%$ to $6 \%$ because of a decline in Harpalus rufipes.

\section{Spider species richness and abundance}

In the first post-fire year, the spider assemblage at the Morozova Gora site was represented by 21 species from seven families (Appendix, Table 2). The most speciose Gnaphosidae included eight species, and the Lycosidae four species. The lycosids were also the most numerous, as the two superdominant species, Xerycosa minita and Alopecosa trabalis, belonged to this family. The third species of the dominant complex, Haplodrassus signifer, belonged to the Gnaphosidae (Figure 12), and together these comprised $73.3 \%$ of spiders in this habitat.

During the same year, 20 spider species from nine families were recorded at control-1, the families Lycosidae and Gnaphosidae were the most species-rich (six and five species, respectively). The dominant complex included only lycosids (Figure 12), and comprised 51\% of the total number of individuals. At control-2, spider species composition was richer (32 species from ten families), the Gnaphosidae numbered nine species and the

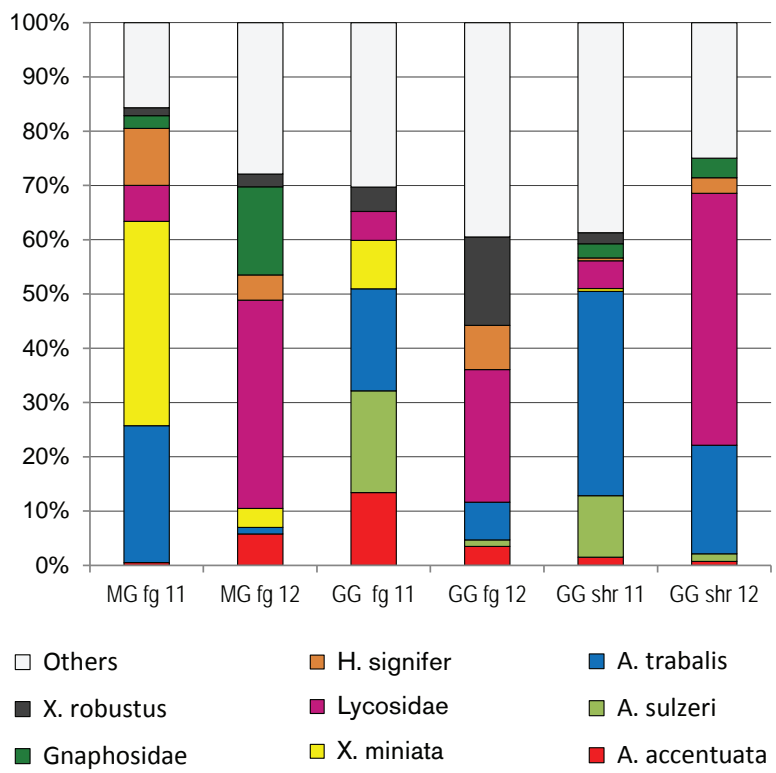

Figure 12: Relative abundance of dominant spider species at the burnt and unburnt plots. For abbreviations, see Figure 7.

Slika 12: Relativna abundanca prevladujočih vrst pajkov na pogorelih in nepogorelih ploskvah. Za okrajšave glej sliko 7 . 
Lycosidae eight species. Alopecosa trabalis was a prevailing superdominant, comprising $37.6 \%$ of the spiders in the habitat, and A. sulzeri constituted 11\% (Figure 10). The dominant complex included only these two species.

In late May - early August of the second post-fire year, we collected only 13 spider species from the burnt plot. The dominant complex consisted of juvenile specimens of Lycosidae and Gnaphosidae (Figure 12); the most abundant species were Alopecosa accentuata, A. cuneata, and Haplodrassus signifer. At control-2, the species composition also decreased (22 species), while at control- 1 it remained at the same level as in the previous year $(21$ species). Both plots were dominated by juvenile lycosids (Figure 12). Adult Xysticus robustus (Thomosidae) prevailed at the first plot, while Alopecosa trabalis (Lycosidae) was abundant at the second one.

The April-May sampling in 2012 added six species at the burnt plot. Alopecosa accentuata (43\% of all individuals), Thanatus formicinus, Asianellus festivus and young Salticidae ( $8 \%$ each) were the most abundant species in the spring spider assemblage. Four additional species were found at control-1, and six species at control-2. Both plots were dominated by lycosids only: $A$. accentuata and A. cuneata ( $27 \%$ each) at the first plot, and $A$. cuneata (28\%), A. trabalis (24.8\%) and A. accentuata (14.7\%) at the second one.

During the sampling period, the seasonal dynamics of the spider assemblages had a peak of species richness in May-June 2011 (Figure 13). Moreover, at this time the difference between the number of spider species at the burnt and both unburnt plots was the highest. In general, the curve of species richness at the burnt plot was smoother and lower than that at the unburnt plots. Spider activity density demonstrated similar seasonal changes at all three plots, having a maximum in April-May 2012. In June-July 2011 and April-May 2012, spider abundance was highest at the burnt plot, and only in one case was it lower than at control-1. Spider activity density in May-July 2011 was 32.2, 22.3, and 30.5 individuals/100 trap-days at the burnt, control- 1 and control-2 plots, respectively, and in May - early August 2012 it was 12.5, 10.8 , and 21.5 individuals/100 trap-days.

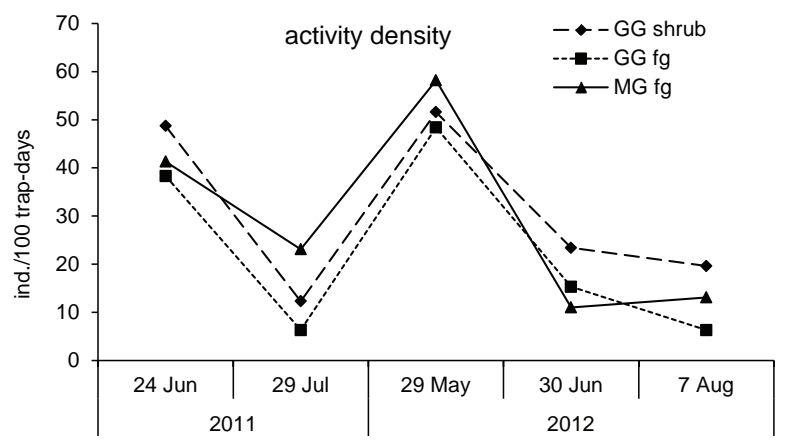

Figure 13: Seasonal dynamics of spider assemblages at the burnt and unburnt plots. For abbreviations, see Figure 7. Figure 13: Sezonska dinamika združb pajkov na pogorelih in nepogorelih ploskvah. Za okrajšave glej sliko 7.
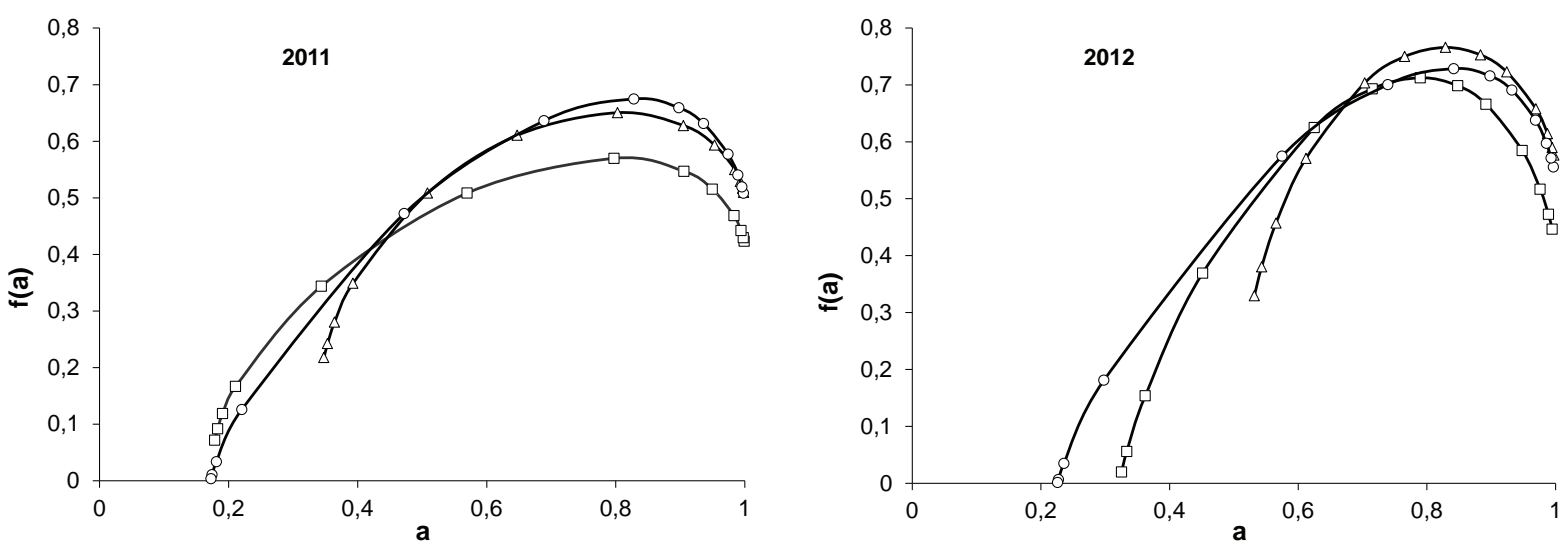

Figure 14: Multifractal spectrum of the spider alpha-diversity at the burnt and unburnt plots. a - singularity index; $\mathrm{f}(\mathrm{a})$ - multifractal spectrum function. - $\square--$ MGfg; - $\Delta-$ - GGfg, - - - - GGshr. For abbreviations, see Figure 7.

Slika 14: Multifraktralni spekter alfa diverzitete pajkov na pogorelih in nepogorelih ploskvah. a - indeks enoličnosti; $\mathrm{f}(\mathrm{a})$ - funkcija multifraktalnega spektra. - - - MGfg; - $\Delta$ - - GGfg, - - - GGshr. Za okrajšave glej sliko 7. 
In 2011, the spider alpha-diversity at the burnt plot was lower than that at both the unburnt plots (Figure 14). Control-1 was characterized by the highest evenness of the spider assemblage. A number of rare species inhabited all the studied plots; their number was lowest at the burnt plot. In 2012, the spider alpha-diversity increased, and the difference between the burnt and unburnt plots diminished.

The DCA showed that spider assemblages were clearly grouped according to the sampling year along Axis 1 (Figure 10). There was nearly no difference between the control plots along this axis. Along Axis 2, annual difference between spider assemblages was lowest at control-1. On both axes, the burnt plot was closer to control-2.

\section{Discussion}

During the two post-fire years, a total of 109 beetle and 29 spider species were recorded from the burnt feather-grass-forb steppe at the Morozova Gora, 114 beetle and 34 spider species from the unburnt plot with the same steppe type at the Galich'ya Gora, and 154 beetle and 43 spider species from the unburnt shrub steppe. Despite the fire, beetle species richness differed insignificantly in the first and second post-fire years at both the feather-grass plots, and almost doubled at the shrub steppe plot. During the sampling period, beetle and spider numbers were lowest at the unburnt feather-grass plot, especially in the second post-fire year. At the other two plots, the groups' annual dynamics were the opposite, with a marked increase in beetle abundance and a decrease in spider abundance.

No pyrophilous beetle species were recorded from the steppe plot. The only species associated with the fire sites, Pterostichus quadrifoveolatus Letz. (Carabidae), was recorded in 2011-2012 from the adjacent oak forest (M. Tsurikov, personal data). Ophonus azureus may be considered a facultatively pyrophilous species, as it was reported to be abundant at a newly burnt steppe (Prishutova \& Arzanov 2004, Savchenko 2009). Xerophilous species attracted by the drier conditions are known to increase in number after a fire (Nemkov \& Sapiga 2010). In our case, only Crypticus quisquilius was particularly numerous in the second post-fire year and Harpalus anxius was recorded mainly from the burnt plot. One of the dominants, Opatrum sabulosum, did not vary much in numbers. Its indifference to the fire event was also observed in the dry bunchgrass steppes (Prishutova \& Arzanov 2004). Other species that were dominant in these dry steppes (Poecilus sericeus, Eodorcadion carinatum F., Tentiria nomas (Pall.)) were more sensitive to the plant associations than to fire.
Among the spiders, four xerophilous species (Steatoda albomaculata, Alopecosa taeniopus, Aelurillus v-insignitus, Zelotes longipes) were only recorded from the burnt steppe. Six species that were recorded from the unburnt steppe (Atypus muralis, Alopecosa pulverulenta, A. sulzeri, Agroeca cupea, A. lutescens, Zelotes electus) were not found at the burnt steppe plot. Nevertheless, they occurred in the other habitats of the Morozova Gora, such as burnt forest edges or limestone slopes, so they cannot be considered to respond negatively to fire.

The same beetle species dominated the burnt and unburnt plots, except Silpha obscura, which preferred the unburnt shrub steppe. The majority of these species are mesophilous generalists, widely distributed in moderately dry grasslands. The fire did not greatly affect the trophic guild structure of the beetle assemblages, though the phytophagous proportion was $10 \%$ lower at the burnt plot, and the necrophagous proportion was higher at the unburnt shrub plot.

The main dominant spider species at the burnt plot in the first post-fire year, Xerolycosa miniata, has been defined as an indicator of disturbed grassland ecosystems in the forest-steppe and steppe zones (Polchaninova 2015). The second dominant, Alopecosa trabalis, is one of the common species of the forest edge and grassy habitats and it was numerous at all the studied plots. In the second year, the difference between dominant spider complexes remained pronounced in April-May, due to the predominance of another generalist grassland species, $A$. accentuata, and low numbers of the mesophilous species, A. cuneata, at the burnt plot. Later in the summer, in contrast to the previous year, all the steppe plots were dominated by juvenile lycosids. This may be explained by the extremely hot spring that resulted in the unusually early completion of the spider life-cycle and emergence of the new generation.

Regionally common generalist and/or xerophilous species dominate burnt steppes in the first post-fire year. For example, juvenile lycosids, gnaphosids, adult Alopecosa accentuata and Xerolycosa miniata, dominated another burnt site of the "Galich'ya Gora" Reserve, a gully with the feather-grass - forb steppe vegetation (Tsurikov \& Polchaninova 2015). The generalist Trochosa terricola was a prevailing dominant in the northern forb-bunchgrass steppe (Polchaninova 2015), juvenile lycosids and adult $A$. solitaria, T. ruricola and Eresus kollari, which are all xerophilous, comprised the dominant complex in the southern forb-bunchgrass steppes (Prokopenko \& Savchenko 2013).

The responses of spider and beetle assemblages to the fire event at the study site were different. The total species richness of beetles and spiders was lowest at the burnt 
plot but during the summer 2012, the species richness decreased in spider assemblages and increased in beetle assemblages. The dominant beetle complexes differed less than the spider ones. The alpha-diversity of beetle assemblages was similar at the three plots during the first year and decreased slightly at the burnt plot in the second year. In contrast, spider alpha-diversity was lowest at the burnt plot during the first year and increased in the second year. In 2012, the beetle activity density increased at the burnt plot and control-2, while that of the spiders decreased. In their seasonal dynamics, both assemblages had a peak of abundance in April-May 2012, but spiders had another, lower one in May-June 2011. Nearly all the traits of spider and beetle assemblages at the study sites were contrasting. The common features of the two groups include maximal species richness in the unburnt shrub steppe, minimal activity density in the unburnt feathergrass - forb steppe, and the most pronounced annual differences at the burnt plot and unburnt shrub steppe plot.

Due to the east-facing position and higher temperature conditions at the Galich'ya Gora site, its feather-grass forb plot is drier than that at the Morozova Gora. This results in the earlier development and lower activity density of both arthropod groups at this plot (Tsurikov 2005), and explains the resemblance of spider assemblage traits at the burnt steppe at Morozova Gora and unburnt shrub steppe at the Galich'ya Gora.

Other studies have also reported differences in the post-fire recovery of spider and beetle assemblages. At the "Bykova Sheya" site (Lipetsk Region, Russia), species richness and activity density in the second post-fire year increased in beetle assemblages but remained at the same level in the spider assemblages (Tsurikov \& Polchaninova 2015). In a sandy forest-steppe habitat in Hungary, fire resulted in a threefold increase in carabid beetle numbers, higher ratio of pioneer species and a simplified assemblage structure. In contrast, for the spider assemblage the changes in species composition and abundance were not significant (Samu et al. 2010). In the dry bunchgrass steppe (Rostov-on-Don Region, Russia), the response of spiders to burning consisted of a small decrease in species richness and abundance, while the number of beetle species and individuals increased markedly at the fire site (Prishutova \& Arzanov 2004). In the forb-bunchgrass steppe (Donetsk Region, Ukraine), the number of beetles just after a spring fire was much higher at the burnt plot, after which the number gradually diminished but still remained higher over the next year (Savchenko 2009). Spider assemblages during the same year were richer in species composition and poorer in number of individuals at the burnt site. In the second year, the difference in species richness disappeared but the difference in number of individuals persisted at the previous level (Prokopenko \& Savchenko 2013).

These studies reported the recovery of arthropod assemblages after patchy small-scale spring fires. In general, changes in the abundance and/or diversity of various taxa were more or less significant only in the first post-fire year, after which the assemblage returned to its previous state. Late-autumn patchy fires also had no significant effects on epigeic arthropods (Valkó et al. 2016).

Previous research has shown that in cases of large-scale summer fires, spider and beetle assemblages change dramatically and do not recover in a three or even five-year period (Nemkov \& Sapiga 2010, Polchaninova 2015). The impact of fire resulted in altered species composition, numbers of individuals and proportions of trophic and ecological groups. In contrast, our investigation has shown that the post-fire recovery of arthropod assemblages at the Morozova Gora site was similar to that in the case of a small-scale spring burning (Savchenko 2009, Prokopenko \& Savchenko 2013). In both cases, annual changes in species composition and numbers were more pronounced than differences between the burnt and unburnt plots. The studied burnt steppe plot at the Morozova Gora occupied only 10 ha and it was located at the edge of a large area of burnt agricultural land. There were patches of undisturbed meadow, forest-edge and steppe vegetation remaining in the immediate vicinity of the fire site. All these factors facilitated post-fire colonization by epigeic arthropods and mitigated the impact of the fire.

It should be emphasized that in all the above-mentioned cases, and indeed in most studies of post-fire recovery of invertebrate assemblages, the material is collected by pitfall-trapping. This method accounts for mobile animals with a high dispersal capacity. They depend on vegetation structure and relief conditions but do not require litter in their microhabitat. Therefore, they are the first to colonize the fire sites, use them as a temporary habitat for feeding, or simply migrate through these habitats. There is significantly less data on the responses of litter-dependent invertebrates, and such studies highlight the duration and difficulty of assemblage recovery (Panzer 2002, Baratt et al. 2009, Polchaninova 2015).

\section{Conclusions}

Our case study has shown that a large-scale summer fire caused no profound changes in the cursorial spider and beetle assemblages. High dispersal capacity of these arthropod groups, the small area of the investigated steppe plot and its location at the edge of the fire site mitigated the severity of the fire's effects. 


\section{References}

Aleksandrova, K.I. 1992: State of regional nature protection in the Lipetsk Region and suggestions of the botanists for improving the protected site system. Bulletin of MOIP. Series biology 97 (5): 107-117 [in Russian].

Archibald, S., Lehmann, C., Gomez-Dans, J. \& Bradstock, R. 2012: Defining pyromes and global syndromes of fire regime. Proceedings of the National Academy of Sciences of the United States of America 110: 6442-6447.

Barratt, B.I.P., Ferguson, C.M., Barton, D.M. \& Johnstone, P.D. 2009: Impact of fire on tussock grassland invertebrate populations. Science for conservation 291: 75 pp.

Bond, W.J. \& Keeley, J.E. 2005: Fire as a global 'herbivore': The ecology and evolution of flammable ecosystems. Trends in Ecology \& Evolution 20 (7): 387-394.

Bowman, D.M.J.S., Balch, J.K., Artaxo, P., Bond, W.J., Carlson, J.M., Cochrane, M.A., D’Antonio, C.M., DeFries, R.S., Doyle, J.C., Harrison, S.P., Johnston, F.H., Keeley, J.E., Krawchuk, M.A., Kull, C.A., Marston, J.B., Moritz, M.A., Prentice, I.C., Roos, C.I., Scott, A.S., Swetnam, T.W., van der Werf, G.R \& Pyne S.J. 2009: Fire in the Earth system. Science 324 (5926): 481-484.

Chibilev, A.A. 2014: Reflections after the fire in the Burtinskaya Steppe. Steppe Bulletin (3): 42-43 [in Russian].

Chuvieco, E., Giglio, L. \& Justice, C. 2008: Global characterization of fire activity: Toward defining fire regimes from earth observation data. Global Change Biology 14: 1488-1502.

Cook, V. \& Holt, R. 2006: Fire frequency and mosaic burning effects on a tallgrass prairie ground beetle assemblage. Biodiversity and Conservation 15: 2301-2323.

Deák, B., Valkó, O., Török, P.,Végvári, Zs., Hartel, T. \& Schmotzer, A. 2014: Grassland fires in Hungary - experiences of nature conservationists on the effects of fire on biodiversity. Applied Ecology and Environmental Research 12 (1): 267-283.

Dedyu, I.I. 1990: Ecological Encyclopedic Dictionary. Main Edition of the Moldavian Soviet Encyclopedia, Kishinev, 406 pp.

Gelashvili, D. B., Iudin, D. I., Rozenberg, G. S., Yakimov, V. N. \& Solntsev, L. A. 2013: Fractals and multifractals in bioecology. PH NNU, Nizhniy Novgorod, 370 pp. [in Russian].

Gelashvili, D. B., Iudin, D. I., Yakimov, V. N., Solntsev, L. A., Rozenberg, G. S., Shurganova, G. V., Okhapkin, A. G., Startseva, N. A., Pukhnarevich, D. A. \& Snegireva, M. S. 2012: Multifractal analysis of the species structure of freshwater hydrobiocenoses. Biology Bulletin 39 (3): 271-278.

Griffiths, A. \& Brook, B. 2014: Effect of fire on small mammals: a systematic review. International Journal of Wildland Fire 23 (7): 1034-1043.

Guseva, N. A. \& Bogach, Y. 1988: Impact of fire on soil surface dwelling Coleoptera of meadow steppe. In: Structure and function of protected forest-steppe ecosystems. Moscow, pp. 56-64 [in Russian].

Hill, M.O. \& Gauch, H.G. 1980: Detrended Correspondence Analysis: an imroved ordination technique. Vegetatio 42: 47-58.
Hammer, Ø., Harper, D.A.T. \& Ryan, P.D., 2001: PAST: Paleontological Statistics Software Package for Education and Data Analysis. Palaeontology Electronic 4, 9 pp. http://folk.uio.no/ ohammer/past

Kitzberger, T., Veblen, T. \& Villalba, R. 1997: Climatic influences of fire regimes along a rain forest-to-xeric woodland gradient in northern Patagonia, Argentina. Journal of Biogeography 24: 35-47.

Kwok, A.B.C. \& Eldridge, D.J. 2015: Does fire affect the grounddwelling arthropod community through changes to fine-scale resource patches? International Journal of Wildland Fire 24 (4): 550-559.

Nedosekina, T.V., Grigorievskaya, A.Y., Khlyzova, N.Y. \& Slavgorodsky, A.V. 2009: Plant communities of the Lipetsk Area (Cadastre). PPC VSU, Voronezh, 199 pp. [in Russian].

Nemkov, V.A. \& Sapiga, E.V. 2010: Impact of fires on the fauna of terrestrial arthropods in protected steppe ecosystems. Russian Journal of Ecology 41(2): 173-179.

New, T.R. 2015: Insects, fire and conservation. Springer International Publishing, Switzerland. 208 p.

Orgeas, J. \& Andersen, A. 2001: Fire and biodiversity: Responses of grass-layer beetles to experimental fire regimes in an Australian tropical savanna. Journal of Applied Ecology 38: 49-62.

Panzer, R. 2002: Compatibility of prescribed burning with the conservation of insects in small, isolated prairie reserves. Conservation Biology 16 (5): 1296-1307.

Parr, C.L. \& Chown, S.L. 2003: Burning issues for conservation: a critique of faunal fire research in Southern Africa. Australian Ecology 28 (4): 384-395.

Parr, C.L. \& Chown, S.L. 2006: Burning for biodiversity conservation a critique of the pyrodiversity paradigm. Conservation Biology 20 (6): 1610-1619.

Polchaninova, N. 2015: Recovery of spider communities after a spontaneous summer fire in the forb-bunchgrass steppe of eastern Ukraine. Hacquetia 14 (1): 79-96.

Prishutova, Z. G. \& Arzanov, Y. G. 2008: Influence of the local steppe fire on the gerpetobionts. In: Trudy gosudarstvennogo prirodnogo zapovednika 'Rostovskiy' vypusk 4. 'Donskoi Izdatelskiy Dom', Rostov-on-Don, pp. 192-208 [in Russian, with English summary].

Prodon, R., Fons, R. \& Athias-Binche, F. 1987: The impact of fire on animal communities in the Mediterranean area. In: The role of fire in ecological systems. L. Trabaud. (ed.). SPB Academic, The Hague, pp. 121-157.

Prokopenko, E. V. \& Savchenko, E. Y. 2013: An influence of the steppe fire on fauna and spiders population structure (Aranei, Arachnida) in «Kamennye Mogyly» reserve (Volodarskiy Region, Donetskaya Oblast). Biological bulletin of Bogdan Chmelnitskiy Melitopol state pedagogical university, 1 (7): 90-105 [in Russian, with English summary].

Richards, S.A., Possingham, P. H. \& Tizard, J. 1999: Optimal fire management for maintaining community diversity. Ecological Applications 9 (3): 880-892.

Robinson, N.M., Leonard, S.W.J., Ritchie, E.G., Bassett, M., Chia, E.K., Buckingham, S., Gibb, H., Bennett, A.F. \& Clarke, M.F. 2013: 
Refuges for fauna in fire-prone landscapes: their ecological functions and importance. Journal of Applied Ecology 50: 1321-1329.

Sackmann, P. \& Farji-Brener, A. 2006: Effect of fire on ground beetle and ant assemblages along an environmental gradient in NW Patagonia: Does habitat type matter? Ecoscience 13 (3): 360-371.

Samu, F., Kádár, F., Ónodi, G., Kertész, M., Szirányi, A., Szita, É., Fetykó, K., Neidert, D., Botos, E. \& Altbäcker, V. 2010: Differential ecological responses of two generalist arthropod groups, spiders and carabid beetles (Araneae, Carabidae), to the effects of wildfire. Community Ecology 11 (2): 129-139.

Savchenko, K. Yu. 2009: Pyrogenic factor influence on surfacedwelling Coleoptera in the forbs-fescue-feather grass steppe. Kharkov Entomological Society Gazette 17 (1-2): 67-73 [in Russian, with English summary].

Skufyin, K.V. 1978. Insects of the southeast of the Black Earth Centre. PH VGU, Voronezh, 163 pp. [in Russian].

Southword, T.R.E. 1978: Ecological methods. Chapman and Hall, London. 253 pp.

Swengel A. B. 1996: Effects of fire and hay management on abundance of prairie butterflies. Biological Conservation 76: 73-85.

Swengel, A. B. 2001. A literature review of insect responses to fire, compared to other conservation managements of open habitat.
Biodiversity and Conservation 10: 1141-1169.

Tsurikov, N.M. 2005: Faunistic relations of the beetles (Coleoptera, Insecta) of "Galich'ya Gora" Nature Reserve and mountain ecosystems of Eurasia. In: Mountain ecosystems and their components: Book of Materials of the International Conference (4-9 September 2005, Nalchik). Volume 2. Nalchik, pp. 162-163 [in Russian].

Tsurikov, N.M. \& Polchaninova, N.Y. 2015: Post-fire recovery of the ground dwelling beetles (Coleoptera) and spiders (Araneae) in the steppe gully "Bykova Sheya” (Lipetsk Region, Russia). In: Steppes of the Northern Eurasia: Materials of the VII International Symposium. A.A. Chibilev (ed.). IS UrD RAS, SPB “Dimiur”, Ornburg, pp. 899-903 [in Russian, with English summary].

Valkó, O., Deák, B., Magura, T., Török, P., Kelemen, A., Tóth, K., Horváth, R., Nagy, D., Debnár, Z., Zsigrai, G., Kapocsi, I. \& Tóthmérész, B. 2016. Supporting biodiversity by prescribed burning in grasslands - A multi-taxa approach. Science of the Total Environment http://dx.doi.org/10.1016/j.scitotenv.2016.01.184

Vassiliev, V.P. 1987: Pests of the agricultural crops and forest plantations. Volume 1. Harmful nematodes, mollusks and arthropods. Second edition. "Urozhai", Kyiv, 440 pp. [In Russian].

Vogel, J.A., Koford, R. \& Debinski, D. 2010: Direct and indirect responses of tallgrass prairie butterflies to prescribed burning. Journal of Insect Conservation 14: 663-677.

\section{Appendix}

Table 1: Beetle species and numbers of individuals collected in the burnt (Morozova Gora) and unburnt (Galich'ya Gora) steppe on $24^{\text {th }}$ May-29 $9^{\text {th }}$ July 2011 and $26^{\text {th }}$ April-4 $4^{\text {th }}$ August 2012 at the "Galich'ya Gora" Nature Reserve.

Tabela 1: Vrste hroščev in število osebkov nabranih v pogoreli (Morozova Gora) in nepogoreli stepi (Galičija Gora) 24.5.-29.7. 2011 in 26.4.-4.8. 2012 v naravnem rezervatu "Galičija Gora".

\begin{tabular}{lcccccc} 
& Morozova Gora & & \multicolumn{3}{c}{ Galich'ya Gora } \\
Species & feather-grass & forb steppe & feather-grass - & forb steppe & shrub steppe \\
& 2011 & 2012 & 2011 & 2012 & 2011 & 2012 \\
\hline
\end{tabular}

\section{Family Carabidae}

Leistus ferrugineus (Linnaeus, 1758)

Notiophilus germinyi Fauvel, 1863

Cylindera germanica (Linnaeus, 1758)

Calosoma investigator (Illiger, 1798)

Carabus cancellatus Illiger, 1798

C. marginalis Fabricius, 1794

C. estreicheri Fiscer von Waldheim, 1820

C. sibiricus Fiscer von Waldheim, 1820

Brachinus crepitans (Linnaeus, 1758)

Bembidion quadrimaculatum (Linnaeus, 1761)

Callistus lunatus Fabricius, 1775

Harpalus affinis (Schrank, 1781)

$H$. anxius (Duftschmid, 1812)

$\begin{array}{cc}. & \\ . & 1 \\ \cdot & \cdot \\ \cdot & \cdot \\ \cdot & 1 \\ \cdot & 1 \\ . & \cdot \\ . & \cdot \\ 3 & 4 \\ \cdot & \cdot \\ \cdot & \cdot \\ . & \cdot \\ 28 & \cdot \\ \cdot & 1 \\ . & 2\end{array}$

H. caspius (Steven, 1806)

H. distinguendus (Duftschmid, 1812)

$\cdot$
$\cdot$
$\cdot$
$\cdot$
$\cdot$
$\cdot$
$\cdot$
$\cdot$
$\cdot$
$\cdot$
1
11
1
$\cdot$
2

$\begin{array}{ccc}1 & 2 & 1 \\ . & \cdot & \cdot \\ 1 & \cdot & \cdot \\ \cdot & \cdot & 13 \\ . & 1 & 2 \\ . & 3 & 7 \\ . & 2 & 1 \\ . & 2 & 1 \\ . & \cdot & 9 \\ \cdot & \cdot & 2 \\ . & \cdot & \cdot \\ \cdot & 1 & \cdot \\ . & \cdot & \cdot \\ . & \cdot & \cdot \\ 1 & 2 & \end{array}$




\begin{tabular}{llllll} 
& Morozova Gora & \multicolumn{3}{c}{ Galich'ya Gora } \\
Species & feather-grass - & feather-grass - & shrub steppe \\
& forb steppe & forb steppe & 20112 & 2012 \\
\hline
\end{tabular}

H. latus (Linnaeus, 1758)

$7 \quad 5$

H. pumilus Sturm, 1818

H. rubripes (Duftschmid, 1812)

1

1

1

H. tardus (Panzer, 1796)

H. zabroides Dejean, 1829

H. griseus (Panzer, 1796)

H. rufipes (DeGeer, 1774)

H. signaticornis (Duftschmid, 1812)

Ophonus azureus (Fabricius, 1775)

O. laticollis Mannerheim, 1825

O. puncticollis (Paykull, 1798)

O. stictus Stephens, 1828

Bradycellus caucasicus (Chaudoir, 1846)

Cymindis angularis Gyllenhal, 1810

Microlestes minutulus (Goeze, 1777)

Syntomus obscuroguttatus Duftschmid, 1812

S. truncatellus (Linnaeus, 1761)

Licinus cassideus Fabricius, 1792

L. depressus (Paykull, 1790)

Odacantha melanura (Linnaeus, 1767)

Panagaeus bipustulatus (Fabricius, 1775)

Agonum gracilipes (Duftschmid, 1812)

Anchomenus dorsalis (Pontoppidan, 1763)

Poecilus crenuliger (Chaudoir, 1876)

P. punctulatus (Schaller, 1783)

P. sericeus Fiscer von Waldheim, 1824

P. versicolor (Sturm, 1824)

Pterostichus strenuus (Panzer, 1796)

Calathus fuscipes (Goeze, 1777)

C. ambiguus (Paykull, 1790)

C. erratus (C.R. Sahlberg, 1827)

Amara aenea (DeGeer, 1774)

A. communis (Panzer, 1797)

A. eurynota (Panzer, 1796)

A. ovata (Fabricius, 1792)

A. bifrons (Gyllenhal, 1810)

A. infima (Duftschmid, 1812)

A. ingenua (Duftschmid, 1812)

A. equestris (Duftschmid, 1812)

Z. spinipes Fabricius, 1798

Z. tenebrioides (Goeze, 1777)

\section{Family Histeridae}

Margarinotus bipustulatus (Schrank, 1781)

Hypocacculus rubripes Erichson, 1834

Hypocaccus metallicus (Herbst, 1792)

Saprinus aeneus (Fabriceus, 1775)

S. virescens Paykull, 1798

\section{Family Leiodidae}

Catops nigricans Spence, 1815 


\begin{tabular}{ccccccc} 
& Morozova Gora & & \multicolumn{3}{c}{ Galich'ya Gora } \\
Species & feather-grass - & feather-grass - & shrub steppe \\
& forb steppe & forb steppe & 2012 & 2011 & 2012 \\
\end{tabular}

Agathidium laevigatum Erichson, 1845

Leiodes polita (Marsham, 1802)

Family Scydmaenidae

Stenichnus collaris (P.W.J. Müller \& Kunze, 1822)

Family Silphidae

Silpha carinata Herbst, 1783

S. obscura Linnaeus, 1758

Thanatophilus sinuatus (Fabricius, 1775)

Nicrophorus antennatus Reitter, 1885

$N$. investigator Zetterstedt, 1824

Family Staphylinidae

Anthobium atrocephalum (Gyllenhal, 1827)

Clavigertes taceus Preyssler, 1790

Sepedophilus marshami (Stephens, 1832)

Aleochara erythroptera Gravenhorst, 1806

A. accepta Ljkovský, 1972

Athetam alleus Joy, 1913

Dinaraea aequata (Erichson, 1837)

Drusilla canaliculata (Fabricius, 1787)

Zyras limbatus (Paykull, 1789)

Oxypoda vicina Kraatz, 1858

Coprophilus piceus (Solsky, 1866)

Anotylus insecatus (Gravenhorst, 1806)

A. nitidulus (Gravenhorst, 1802)

Achenium humile (Nicolai, 1822)

Sunius melanocephalus (Fabricius, 1793)

Paederus littoralis Gravenhorst, 1802

Philonthus lepidus (Gravenhorst, 1802)

Ph. Rubripennis Stephens, 1832

Ocypus brunnipes (Fabricius, 1781)

O. nitens (Schrank, 1781)

O. ophthalmicus (Scopoli, 1763)

O. fulvipennis Erichson, 1840

Platydracus latebricola (Gravenhorst, 1806)

P. stercorarius (Olivier, 1795)

Tasgius melanarius (Heer, 1839)

Family Scarabaeidae

Pleurophorus caesus (Creutzer, 1796)

Onthophagus ovatus (Linnaeus, 1758)

Melolontha melolontha (Linnaeus, 1758)

Maladera holosericea (Scopoli, 1772)

Cetonia aurata (Linnaeus, 1761)

Tropinota hirta (Poda von Neuhaus, 1761)

Family Eucinetidae

Eucinetus haemorrhoidalis (Germar, 1818)

$\begin{array}{llllll}\cdot & \cdot & \cdot & \cdot & \cdot & 4 \\ . & \cdot & \cdot & \cdot & \cdot & 1\end{array}$

4

1

107

$\begin{array}{cc}14 & 12 \\ 166 & 341 \\ 1 & \cdot \\ 5 & 1 \\ 5 & \cdot\end{array}$

Family Buprestidae

Agrilus hastulifer Ratzeburg, 1837

Cylindromorphus filum (Gyllenhall, 1817)

Coraebus elatus (Fabricius, 1787) 


\begin{tabular}{|c|c|c|c|c|c|c|}
\hline \multirow{3}{*}{ Species } & \multirow{2}{*}{\multicolumn{2}{|c|}{$\begin{array}{l}\text { Morozova Gora } \\
\text { feather-grass - } \\
\text { forb steppe }\end{array}$}} & \multicolumn{4}{|c|}{ Galich'ya Gora } \\
\hline & & & \multicolumn{2}{|c|}{$\begin{array}{l}\text { feather-grass - } \\
\text { forb steppe }\end{array}$} & \multicolumn{2}{|c|}{ shrub steppe } \\
\hline & 2011 & 2012 & 2011 & 2012 & 2011 & 2012 \\
\hline Trachys fragariae Brisout de Barneville, 1874 & . & . & . & 2 & . & 4 \\
\hline T. problematica Obenberger, 1918 & . & 1 & . & . & . & . \\
\hline T. pumila (Illiger, 1803) & . & 1 & . & . & . & . \\
\hline T. scrobiculata Kiesenwetter, 1857 & . & . & . & . & . & 1 \\
\hline \multicolumn{7}{|l|}{ Family Byrrbidae } \\
\hline Lamprobyrrhulus nitidus (Schaller, 1783) & . & . & 2 & . & . & . \\
\hline Byrrhus pilula (Linnaeus, 1758) & 1 & . & 1 & . & . & . \\
\hline Cytilus sericeus (Forster, 1771) & . & 1 & . & . & . & . \\
\hline \multicolumn{7}{|l|}{ Family Elateridae } \\
\hline Agrypnus murinus (Linnaeus, 1758) & 6 & . & 2 & 2 & 2 & 5 \\
\hline Agriotes obscurus (Linnaeus, 1758) & . & . & 1 & . & 2 & . \\
\hline A. sputator (Linnaeus, 1758) & 24 & 2 & . & 1 & 10 & 3 \\
\hline Melanotus brunnipes (Germar, 1824) & . & . & . & . & 1 & . \\
\hline Limonius minutus (Linnaeus, 1758) & . & 3 & 1 & 1 & . & . \\
\hline Prosternontes sellatum (Linnaeus, 1758) & 1 & 1 & . & . & 7 & 10 \\
\hline Selatosomus latus Fabricius, 1801 & . & 1 & . & . & . & . \\
\hline \multicolumn{7}{|l|}{ Family Cantharidae } \\
\hline Cantharis livida Linnaeus, 1758 & . & . & . & . & . & 1 \\
\hline \multicolumn{7}{|l|}{ Family Dermestidae } \\
\hline Dermestes laniarius Illiger, 1801 & 98 & 164 & 105 & 274 & 129 & 377 \\
\hline
\end{tabular}

\section{Family Ptinidae}

Ptinus rufipes A.G. Olivier, 1790

P. villiger (Reitter, 1884)

Family Malachiidae

Apalochrus femoralis (Erichson, 1840)

Family Nitidulidae

Glischrochilus quadrisignatus Say, 1835

Meligethes sp.

Family Phalacridae

Olibrus bicolor (Fabricius, 1792)

O. millefolii (Paykull, 1800)

Phalacrus corruscus (Panzer, 1797)

Family Cryptophagidae

Cryptophagus lycoperdi (Scopoli, 1763)

C. pilosus Gyllenhal, 1827

Family Coccinellidae

Hyperaspis erythrocephala (Fabricius, 1787)

H. reppensis (Herbst, 1783)

Nephus redtenbacheri (Mulsant, 1846)

Scymnus frontalis (Fabricius, 1787)

Platynaspis luteorubra (Goeze, 1777)

Psyllobora vigintiduopunctata (Linnaeus, 1758)

Coccinula quatuordecimpustulata (Linnaeus, 1758)

C. septempunctata Linnaeus, 1758

FamilyLatridiidae

Corticaria impressa (A.G. Olivier, 1790)

C. minuta (Fabricius, 1792)

C. similata (Gyllenhal, 1827)

\section{Family Mordellidae}




\begin{tabular}{|c|c|c|c|c|c|}
\hline \multirow{3}{*}{ Species } & \multirow{2}{*}{$\begin{array}{l}\text { Morozova Gora } \\
\text { feather-grass - } \\
\text { forb steppe }\end{array}$} & \multicolumn{4}{|c|}{ Galich'ya Gora } \\
\hline & & $\begin{array}{r}\text { feat } \\
\text { for }\end{array}$ & $\begin{array}{l}\text { ass - } \\
\text { pe }\end{array}$ & shr & ppe \\
\hline & 2012 & 2011 & 2012 & 2011 & 2012 \\
\hline
\end{tabular}

Mordellistena parvuliformis Stchegoleva-Barovskaya, 1930

.

M. tarsata Mulsant, 1856

M. pseudonotata Ermisch, 1956

Family Tenebrionidae

Lagria hirta (Linnaeus, 1758)

L. laticollis Motschulsky, 1860

Blaps lethifera Marsham, 1802

B. halophila Fischer von Waldheim, 1820

Nalassus brevicollis (Steven, 1832)

Opatrum sabulosum (Linnaeus, 1760)

Pedinus femoralis (Linnaeus, 1767)

Oodescelis melas (Fischer von Waldheim, 1823)

O. polita (Sturm, 1807)

Crypticus quisquilius (Linnaeus, 1760)

Family Oedemeridae

Oedemera virescens (Linnaeus, 1767)

\section{Family Meloidae}

Meloë brevicollis Panzer, 1793

M. proscarabaeus Linnaeus, 1758

M. violaceus Marsham, 1802

Family Anthicidae

Anthicus antherinus (Linnaeus, 1760)

Hirticollis hispidus (Rossi, 1792)

Notoxus monoceros (Linnaeus, 1760)

\section{Family Scraptiidae}

Anaspis subtilis Hampe, 1871

Family Cerambycidae

Pachytodes erraticus Dalman, 1817

Stenurella melanura (Linnaeus, 1758)

Dorcadion holosericeum Krynicki, 1832

Phytoecia scutellata (Fabricius, 1792)

Family Chrysomelidae

Spermophagus ericeus (Geoffroy, 1785)

Bruchus sibiricus Germar, 1824

Crioceris duodecimpunctata (Linnaeus, 1758)

C. quatuordecimpunctata (Scopoli, 1763)

C. quinquepunctata (Scopoli, 1763)

Cassida panzeri Weise, 1907

Hypocassida subferruginea (Schrank, 1776)

Chrysolina limbata limbata (Fabricius, 1775)

Timarcha goettingensis (Linnaeus, 1758)

Galeruca pomonae (Scopoli, 1763)

Sermylas sahalensis (Linnaeus, 1767)

Aphthona nigriscutis Foudras, 1860

A. nonstriata (Goeze, 1777)

Chaetocnema aridula (Gyllenhal, 1827)

Ch. hortensis (Geoffroy, 1785)

Dibolia cryptocephala (Koch, 1803)

Longitarsus medvedevi Shapiro, 1956

\begin{tabular}{|c|c|c|c|c|c|}
\hline . & . & . & 1 & . & . \\
\hline . & 2 & . & . & . & . \\
\hline . & . & . & . & 1 & . \\
\hline . & . & . & . & . & 1 \\
\hline . & . & . & 2 & . & 2 \\
\hline . & . & . & 8 & . & 1 \\
\hline . & 1 & 1 & 2 & . & . \\
\hline 1 & . & . & 4 & 3 & 5 \\
\hline 31 & 192 & 17 & 146 & 5 & 27 \\
\hline . & 3 & 3 & 1 & . & 1 \\
\hline 20 & 116 & 42 & 178 & 9 & 84 \\
\hline . & 3 & 10 & . & . & 1 \\
\hline 85 & 490 & 62 & 99 & 49 & 74 \\
\hline . & . & . & . & 1 & . \\
\hline 2 & 1 & 1 & . & . & . \\
\hline . & . & . & . & . & 1 \\
\hline . & . & . & . & . & 1 \\
\hline . & . & . & . & . & 1 \\
\hline 1 & 4 & . & . & . & . \\
\hline 1 & . & . & . & . & 1 \\
\hline . & . & . & . & . & 3 \\
\hline . & . & . & . & . & 1 \\
\hline . & . & . & . & . & 1 \\
\hline 23 & 6 & 6 & 21 & 2 & . \\
\hline . & . & . & 1 & . & . \\
\hline . & 2 & . & 1 & . & . \\
\hline . & . & . & . & 1 & . \\
\hline . & . & . & 1 & . & . \\
\hline . & . & . & 2 & . & . \\
\hline . & . & . & 10 & . & . \\
\hline . & . & . & . & . & 1 \\
\hline 1 & 1 & 1 & 4 & . & 5 \\
\hline . & . & . & 1 & . & 1 \\
\hline 1 & 1 & . & . & . & 4 \\
\hline 1 & . & . & . & . & . \\
\hline . & . & . & . & . & 54 \\
\hline . & . & . & 1 & . & . \\
\hline . & . & . & 1 & . & . \\
\hline . & 3 & . & 1 & . & 1 \\
\hline . & . & . & . & . & 1 \\
\hline . & 1 & . & . & . & . \\
\hline . & . & . & . & . & 4 \\
\hline
\end{tabular}




\begin{tabular}{ccccccc} 
& Morozova Gora & \multicolumn{3}{c}{ Galich'ya Gora } \\
Species & feather-grass - & feather-grass - & fhrub steppe \\
& forb steppe & forb steppe & 2011 & 2012
\end{tabular}

Longitarsus sp.

Neocrepidodera ferruginea (Scopoli, 1763)

Phyllotreta atra (Fabricius, 1775)

Ph. vittula (L.Redtenbacher, 1849)

Labidostomis lepida Lefèvre, 1872

Cryptocephalus bipunctatus (Linnaeus, 1758)

Pachybrachis scriptidorsis (Marsham,1875)

Family Rhynchitidae

Teretriorhynchites pubescens (Fabricius, 1775)

Family Apionidae

Aspida pionaeneum (Fabricius, 1775)

Exapionelon gatulum (Desbrochers, 1891)

Catapion seniculus (Kirby, 1808)

Betulapion simile (Kirby, 1811)

Family Dryophthoridae

Sphenophorus striatopunctatus (Goeze, 1777)

Family Curculionidae

Xyleborinus saxesenii (Ratzeburg, 1837)

Limnobaris dalmatina Brisout de Barneville, 1870

Rhinusa antirrhini (Paykull, 1800)

Pseudorchestes ermischi Dieckmann, 1958

Tychius quinquepunctatus (Linnaeus, 1758)

Coryssomerus capucinus (Beck, 1817)

Graptus triguttatus (Fabricius, 1775)

Urometopus nemorum L. Arnoldi, 1965

Otiorhynchus raucus (Fabricius, 1777)

O. velutinus Germar, 1824

O ligustici (Linnaeus, 1758)

O. ovatus (Linnaeus, 1758)

Stomodes gyrosicollis (Bohemann, 1843)

Phyllobius brevis Gyllenhal, 1834

Ph. oblongus (Linnaeus, 1758)

Ph. maculicornis Germar, 1824

Polydrusus inustus Germar, 1824

Archeophloeus inermis (Boheman, 1843)

Brachysomus echinatus (Bonsdorff, 1785)

Exomias lebedevi Roubal, 1926

Eusomus ovulum Germar, 1824

Foucartias quamulata (Herbst, 1795)

Sitona inops Schönherr, 1832

S. lineatus (Linnaeus, 1758)

S. macularius (Marsham, 1802)

S. sulcifrons (Thunberg, 1798)

Cycloderes pilosus (Fabricius, 1792)

Cathormiocerus aristatus (Gyllenhal, 1827)

Hypera meles (Fabricius, 1792)

H. miles (Paykull, 1792)

Bothynoderes affinis (Schrank, 1781)

Cleonis pigra (Scopoli, 1763) 


\begin{tabular}{|c|c|c|c|c|c|c|}
\hline \multirow{3}{*}{ Species } & \multirow{2}{*}{\multicolumn{2}{|c|}{$\begin{array}{l}\text { Morozova Gora } \\
\text { feather-grass - } \\
\text { forb steppe }\end{array}$}} & \multicolumn{4}{|c|}{ Galich'ya Gora } \\
\hline & & & \multicolumn{2}{|c|}{$\begin{array}{l}\text { feather-grass - } \\
\text { forb steppe }\end{array}$} & \multicolumn{2}{|c|}{ shrub steppe } \\
\hline & 2011 & 2012 & 2011 & 2012 & 2011 & 2012 \\
\hline Cyphocleonus dealbatus (Gmelin, 1790) & $\cdot$ & $\cdot$ & $\cdot$ & 2 & $\cdot$ & $\cdot$ \\
\hline Pseudocleonus cinereus (Schrank, 1781) & 1 & 4 & 1 & & 1 & 1 \\
\hline Lixus subtilis Bohemann, 1843 & . & . & . & & 1 & . \\
\hline Hylobius abietis (Linnaeus, 1758) & . & 1 & . & 1 & . & . \\
\hline Lepyrus capucinus (Schaller, 1783) & 2 & . & . & . & . & . \\
\hline Liparus coronatus (Goeze, 1777) & 2 & 3 & 4 & 4 & 2 & 8 \\
\hline Total number of individuals & 625 & 1373 & 425 & 1005 & 646 & 1545 \\
\hline \multirow[t]{2}{*}{ Total number of species } & 56 & 90 & 51 & 98 & 64 & 133 \\
\hline & \multicolumn{2}{|c|}{109} & \multicolumn{2}{|c|}{114} & \multicolumn{2}{|c|}{154} \\
\hline
\end{tabular}

Table 2: Spider species with specimens collected in the burnt (Morozova Gora) and unburnt (Galich'ya Gora) steppe on 24 ${ }^{\text {th }}$ May - 29 $9^{\text {th }}$ July 2011 and $26^{\text {th }}$ April $-4^{\text {th }}$ August 2012 at the "Galich'ya Gora" Nature Reserve.

Tabela 2: Vrste pajkov in število osebkov nabranih v pogoreli (Morozova Gora) in nepogoreli stepi (Galičija Gora) 24.5.-29.7. 2011 in 26.4.-4.8. 2012 v naravnem rezervatu "Galičija Gora".

\begin{tabular}{ccccccc}
\hline \multirow{3}{*}{ Species } & \multicolumn{2}{c}{$\begin{array}{c}\text { Morozova Gora } \\
\text { feather-grass - }\end{array}$} & \multicolumn{3}{c}{ Galich'ya Gora } \\
& forb steppe & forb steppe & shrub steppe \\
& 2011 & 2012 & 2011 & 2012 & 2011 & 2012 \\
\hline
\end{tabular}

Asagena phalerata (Panzer, 1801)

Crustulina guttata (Wider, 1834)

Euryopis flavomaculata (C.L. Koch, 1836)

Steatoda albomaculata (De Geer, 1778)

$\begin{array}{lll}1 & \cdot & 1 \\ \cdot & \cdot & \\ \cdot & 1 & \end{array}$

Family Linyphiidae

Ceratinella brevis (Wider, 1834)

Stemonyphantes lineatus (Linnaeus, 1758)

Family Lycosidae

Alopecosa accentuata (Latreille, 1817)

A. cuneata (Clerck, 1757)

A. pulverulenta (Clerck, 1757)

A. sulzeri (Pavesi, 1873)

A. taeniopus (Kulczyński, 1895)

A. trabalis (Clerck, 1757)

Pardosa fulvipes (Collet, 1876)

P. lugubris (Walckenaer, 1802)

Trochosa robusta (Simon, 1876)

T. ruricola (De Geer, 1778)

T. terricola Thorell, 1856

Xerolycosa miniata (C.L. Koch, 1834)

Lycosidae juv.

1

Family Pisauridae

Pisaura novicia (L. Koch, 1878)

Family Miturgidae

Zora spinimana (Sundevall, 1833)

Family Agelenidae

Agelena labyrinthica (Clerck, 1757)

.

.

. 1

Family Titanoecidae

Titanoeca schineri L. Koch, 1872 


\begin{tabular}{lcccccc} 
& Morozova Gora & & \multicolumn{3}{c}{ Galich'ya Gora } \\
Species & feather-grass & feather-grass - & shrub steppe \\
& forb steppe & forb steppe & 2012 & 2011 & 2012 \\
\hline
\end{tabular}

Family Liocranidae

Agroeca cuprea Menge, 1873

A. lusatica (L. Koch, 1875)

Family Phrurolithidae

Phrurolithus festivus (C. L. Koch, 1835)

Family Gnaphosidae

Drassodes pubescens (Thorell, 1856)

Drassyllus praeficus (L. Koch, 1866)

D. pusillus (C. L. Koch, 1833)

Gnaphosa taurica Thorell, 1875

Haplodrassus kulczynskii Lohmander, 1942

H. signifer (C. L. Koch, 1839)

H. umbratilis (L. Koch, 1866)

Micaria formicaria (Sundevall, 1831)

M. fulgens (Walckenaer, 1802)

Phaeocedus braccatus (L. Koch, 1866)

Zelotes aeneus (Simon, 1878)

Zelotes azsheganovae Esyunin, Efimik, 1992

Z. electus (C. L. Koch, 1839)

Z. latreillei (Simon, 1878)

Z. longipes (L. Koch, 1866)

Z. mundus (Kulczyński, 1897)

Z. petrensis (C. L. Koch, 1839)

Z. subterraneus (C. L. Koch, 1833)

Gnaphosidae juv.

Family Philodromidae

Philodromus cespitum (Walckenaer, 1802)

Thanatus arenarius L. Koch, 1872

T. formicinus (Clerck, 1757)

Family Thomisidae

Ozyptila atomaria (Fabricius, 1775)

O. claveata (Walckenaer, 1937)

O. praticola (C. L. Koch, 1837)

O. scabricula (Westring, 1851)

Xysticus cristatus (Clerck, 1758)

X. kochi Thorell, 1872

$X$. luctator L. Koch, 1870

$X$ robustus (Hahn, 1832)

$X$. striatipes L. Koch, 1870

Thomisidae juv.

\section{Family Salticidae}

Aelurillus v-insignitus (Clerck, 1757)

Asianellus festivus (C. L. Koch, 1834)

Evarcha arcuata (Clerck, 1757)

E. laetabunda (C. L. Koch, 1846)

Heliophanus flavipes (Hahn, 1832)

Salticidae juv.

Total number of individuals

Total number of species

$\begin{array}{llllll}. & & 2 & & & \\ . & \cdot & 2 & 2 & 5 & 4\end{array}$

4

\begin{tabular}{|c|c|c|}
\hline & 1 & . \\
\hline 1 & 1 & . \\
\hline 3 & . & 1 \\
\hline . & . & 2 \\
\hline . & . & 1 \\
\hline 22 & 8 & . \\
\hline . & $\cdot$ & 1 \\
\hline . & . & . \\
\hline 3 & . & . \\
\hline$\cdot$ & $\cdot$ & . \\
\hline . & . & . \\
\hline 1 & 1 & . \\
\hline . & . & 6 \\
\hline 1 & . & . \\
\hline 2 & 1 & . \\
\hline · & . & . \\
\hline 1 & . & . \\
\hline 5 & 20 & . \\
\hline 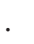 & . & . \\
\hline . & 2 & . \\
\hline 1 & . & 1 \\
\hline
\end{tabular}

$$
\begin{array}{lll}
2 & 4 & 2 \\
3 & 3 & 1 \\
1 & . & .
\end{array}
$$

2

3$$
3
$$$$
3
$$$$
2
$$$$
11
$$$$
14
$$$$
2
$$ 